University of Denver

Digital Commons @ DU

All Publications

Colorado Legislative Council Research

Publications

1987

\title{
0318 Water Quality and Water Resources
}

Colorado Legislative Council

Follow this and additional works at: https://digitalcommons.du.edu/colc_all

\section{Recommended Citation}

Colorado Legislative Council, "0318 Water Quality and Water Resources" (1987). All Publications. 326. https://digitalcommons.du.edu/colc_all/326

This Article is brought to you for free and open access by the Colorado Legislative Council Research Publications at Digital Commons @ DU. It has been accepted for inclusion in All Publications by an authorized administrator of Digital Commons@DU. For more information, please contact jennifer.cox@du.edu,dig-commons@du.edu. 
Report to the Colorado General Assembly:

RECOMMENDATIONS FOR 1988

\section{WATER QUALITY AND \\ WATER RESOURCES}

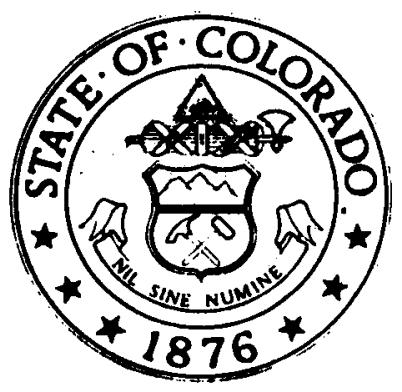

COLORADO LEGISLATIVE COUNCIL

RESEARCH PUBLICATION NO. 318 December, 1987 


\title{
LEGISLATIVE COUNCIL
}

\author{
OF THE
}

COLORADO GENERAL ASSEMBLY

\section{Senators}

Sen. Ted L. Strickland, Chairman

Sen. Wayne Allard

Sen. Jana Mendez

Sen. Harold McCormick

Sen. Ray Peterson

Sen. Ray Powers

Sen. Jeff Wells
Representatives

Rep. Carl B. "Bev" Bledsoe, Vice Chairman

Rep. Vickie Armstrong

Rep. Charles Berry

Rep. Chris Paulson

Rep. Gilbert Romero

Rep. Paul Schauer

Rep. Ruth Wright

The fourteen-member Legislative Council serves as the fact-finding and information-collecting agency of the General Assembly. The Speaker of the House and the Majority Leader of the Senate serve ex officio with twelve appointed legislators -- six senators and six representatives.

Between sessions, the interim legislative committees concentrate on specific study assignments approved by resolution of the General Assembly or directed by the council. Committee documents, data, and reports are prepared with the aid of the council's professional staff.

During sessions, the council staff provides support services to the various committees of reference and furnishes individual legislators with facts, figures, arguments, and alternatives. 
COLORADO LEGISLATIVE COUNCIL RECOMMENDATIONS FOR 1988

COMMITTEE ON

WATER QUALITY AND WATER RESOURCES

\author{
Legislative Council \\ Report to the \\ Colorado General Assembly
}

Research Publication No. 318

December, 1987 
OFFICEAS

Sen. Ted L. Strickland Chairman

Rep. Carl B. "Bev" Bledsoe

Vice Chairman

STAFF

Charles S. Brown

Director

David Hite

Assistant Director

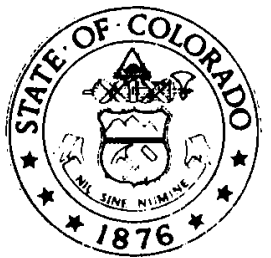

\section{LEGISLATIVE COUNCIL}

ROOM 029 STATE CAPITOL

DENVER, COLORADO 80203-1784

(303) $866-3521$
Sen. Wayne Allard Sen. Harold McCormick Sen. Jana Mendez Sen. Ray Peterson Sen. Ray Powers Sen. Jeffrey Wells Rep. Vickie Armstrong Rep. Charles Berry

Rep. Chris Paulson Rep. Gilbert Romero Rep. Paul Schauer Rep. Ruth Wright

To Members of the Fifty-sixth Colorado General Assembly:

Submitted herewith is the final report of the Committee on Water Quality and Water Resources. The committee was appointed by the Legislative Council pursuant to House Joint Resolution No. 1032, 1987 session.

At its meeting on November 15, 1987, the Legislative Council reviewed this report and approved a motion to forward the committee's recommendations to the Fifty-sixth General Assembly.

Respectfully submitted,

\author{
/s/ Senator Ted L. Strickland \\ Cha irman \\ Colorado Legislative Council
}

TLS/pn 
TABLE OF CONTENTS $\ldots \ldots \ldots \ldots \ldots \ldots \ldots \ldots \ldots \ldots \ldots \ldots \ldots \ldots \ldots$

LIST OF BILLS AND RESOLUTIONS $\ldots \ldots \ldots \ldots \ldots \ldots \ldots \ldots \ldots \ldots \ldots \ldots$. $\ldots \ldots \ldots$

COMMITTEE ON WATER QUALITY AND WATER RESOURCES

Members of Committee $\ldots \ldots \ldots \ldots \ldots \ldots \ldots \ldots \ldots \ldots \ldots \ldots \ldots$

Summary of Recommendations $\ldots \ldots \ldots \ldots \ldots \ldots \ldots \ldots \ldots \ldots$ Committee Charge ........................... 3

Committee Recommendations ................. 4

Protection of Drinking water $\ldots \ldots \ldots \ldots \ldots \ldots \ldots \ldots \ldots$

Water Pollution Control Revolving Fund ........... 5

Water Quality Control Act .................... 5

Time Not ice Change .................... 5

Permits System Fees $\ldots \ldots \ldots \ldots \ldots \ldots \ldots \ldots \ldots \ldots 6$

Water Quality Authority .................... 6

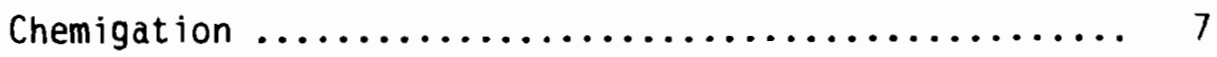

Interstate Compact Requirements $\ldots \ldots \ldots \ldots \ldots \ldots \ldots 7$

Authorization of Water Projects .............. 7

404 Dredge and Fill Permit .................... 8

Other Committee Activities .................... 8

Background Report $\ldots \ldots \ldots \ldots \ldots \ldots \ldots \ldots \ldots \ldots \ldots \ldots$

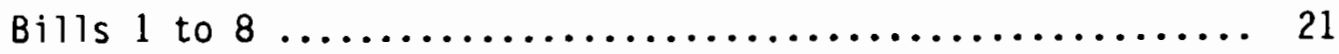

Joint Resolution $A \ldots \ldots \ldots \ldots \ldots \ldots \ldots \ldots \ldots \ldots \ldots \ldots$ 
BILL 1 -- Concerning the Protection of Drinking Water, and, in Connection Therewith, Conforming the State Drinking Water Protection Provisions to the Requirements of the 1986 Amendments to the Federal "Safe Drinking Water Act", Adopting Minimum General Sanitary Standards for Drinking Water in the Absence of Federally Promulgated Standards, Establishing a Laboratory Certification Program, and Providing for the Enforcement of Drinking Water Standards and Protection of Drinking Water Supplies.

BILL 2 -- Concerning Authorization for the State to Participate in the Water Pollution Control Revolving Fund Created by the Federal "Water Quality Act of $1987 "$ by Providing for the Creation of a State Water Pollution Control Revolving Fund, and Relating to the Administration Thereof.

BILL 3 -- Concerning Amendments to the "Colorado Water Quality Control Act".

BILL 4 -- Concerning Water Quality Control Permits System Fees.

BILL 5 -- Concerning the Creation of the Cherry Creek Basin Water Quality Authority.

BILL 6 -- Concerning Amendments to the "Colorado Chemigation Act", and Relating to the Definitions of "Chemigation" and "Irrigation", an Increase in the Permit and Inspection Fees, and the Penalties Provided for Violations of the Act.

BILL 7 -- Concerning an Appropriation to the Department of Natural Resources for Allocation to the State Engineer.

BILL 8 -- Concerning Projects Funded by the Colorado Water Conservation Board Construction Fund, and Relating to the Activities of the Colorado Water Conservation Board in Connection Therewith.

JR A -- Requesting That the United States Army Corps of Engineers Consolidate Their District Boundaries in Colorado. 


\title{
LEGISLATIVE COUNCIL
}

COMMITTEE ON WATER QUALITY AND WATER RESOURCES

\section{Members of the Committee}

Rep. Dan Williams, Chairman

Sen. Tilman Bishop, vice Chairman

Sen. Wayne Allard

Sen. Steve Durham

Sen. Jana Mendez

Sen. Ray Peterson
Rep. Don Ament

Rep. Leo Berger

Rep. Ed Carpenter

Rep. Lewis Entz

Rep. Margaret Masson

Rep. Tom Norton

Rep. Jeannie Reeser

Rep. Sam Williams

\section{Council Staff}

Jim Hill

Senior Analyst
Scott Nachtrieb

Research Associate

\author{
Legislative \\ Drafting Staff \\ John Berry \\ Senior Attorney
}


SUMMARY OF RECOMMENDATIONS

\section{Committee Charge}

Pursuant to House Joint Resolution 1032, the committee was charged with conducting a comprehensive study of various water quality and water resource issues. Included were matters relating to the protection and maintenance of drinking water standards, maintaining the state's water quality control program, and the management of surface and groundwater resources. Specifically, the study directive included the following water quality and water management issues:

a) the current level, effectiveness and appropriateness of state and federal regulations governing drinking water;

b) the desirability and cost of continuing a full state water quality control program in view of criticism by the Environmental Protection Agency of the current state program and the Environmental Protection Agency oversight which results in duplication and overturning of state regulatory actions;

c) the need to provide for more specific guidelines under the definition of minimum general sanitary standards, taking into consideration any standards promulgated by the federal government under the "Safe Drinking Water Act" and, if no such standards have been so promulgated, providing the Department of Health with authority to promulgate its own standards;

d) consideration of other provisions necessary to assure that this state's drinking water is fit for consumption and is not a threat to public health;

e) the management and development of our surface water resources;

f) the management of our groundwater resources;

g) meeting our interstate water compact requirements;

h) maintaining water quality; and

i) recommendations relating to coordination of the activities of the various state agencies which have responsibilities relating to these water issues. 
The eight bills and one resolution recommended for the 1988 sessiton are the product of seven days of committee meetings. Two of the committee's hearings were held in Colorado Springs, in conjunction with, the Colorado Water Congress annual conference. In the course of these meetings, consideration was given to all nine topics assigned the committee.

\section{Committee Recommendations}

The committee offers the following recommendations for favorable consideration by the 1988 session of the Colorado General Assembly.

\section{Protection of Drinking water}

Bill 1-- Concerning the Protection of Drinking Water, and, in Connection Therewith, Conforming the State Orinking Water Protection Provisions to the Requirements of the 1986 Amendments to the Federal "Safe Drinking Water Act", Adopting Minimum -General Sanitary Standards for Drinking Water in the Absence of Federally Promulgated Standards, Establishing a Laboratory Certification Program, and Providing for the Enforcement of Orinking Water Standards and Protection of Drinking Water Supplies

With the passage of amendments to the federal Safe Drinking Water Act and concerns regarding those cohtaminants not covered by federal standards, the committee recommends changes to Colorado's drinking water protection laws. Bill 1 conforms Colorado drinking water protection statutes with the requirements of amendments to the federal act, and provides authority to set standards for contaminants not covered by federal law.

$i$ The bill has three major sections: the establishment of an annual priority list of contaminants for which standards may be set; authority and criteria for setting standards where federal law is silent; and enforcement. The bill requires the Colorado Department of Health to establish and revise each year a priority list of contaminants for which standards may be considered. It also stipulates that the priority list must be prepared according to a ranking process incorporating various considerations. Following the department's submission of recommended standards, the State Board of Health may adopt minimum general sanitary standards for contaminants not addressed by federal law.

A specific process must be followed by the board in determining standards and a laboratory certification program is established for the purpose of ensuring competent testing of drinking water. Finally, the bill allows local water suppliers and the Colorado Department of Health a cause of action against anyone, including the federal government, who contaminates the water which water suppliers provide to the public. 
Water Pollution Control Revolving Fund

Bill 2 -- Concerning Authorization for the State to Participate in the Water Pollution Control Revolving Fund Created by the Federal "Water Quality Act of 1987" by Providing for the Creation of a State Water Pollution Control Revolving Fund, and Relating to the Administration Thereof

The bill creates the water pollution control revolving fund in the Colorado Water Resources and Power Development Authority to finance construction and maintenance of wastewater treatment facilities. This funding mechanism is necessary due to the federal government shifting the responsibility for financing wastewater treatment facilities to state and local governments. To meet the state's wastewater treatment needs effectively and efficiently, the bill specifies that the expertise of the Division of Water Quality Control, the Division of Local Government, and the authority be utilized in the following manner:

-- the Water Quality Control Division shall develop a project priority list and intended use plan with the other two agencies for wastewater treatment systems, which shall be approved by legislative joint resolution and signed by the Governor;

-- the Water Quality Control Division is designated the lead contact with the Environmental Protection Agency and loan applicants; the division shall also provide technical, engineering, and environmental reviews and determine eligible project costs as well as provide planning, data collection, and files management;

-- the Division of Local Government shall assess financial need, require maximum local effort based on the ability to pay, develop the financial package with the most appropriate form of financial assistance, and structure repayment schedules to the fund; and

-- the Authority shall manage the fund, have the sole discretion to proceed with project financing, and may issue revenue bonds to provide state matching funds for the program.

Water Quality Control Act

Bill 3 -- Concerning Amendments to the "Colorado Water Quality Control Act"

This bill makes several administrative changes in the Colorado Water Quality Control Act, a result of testimony indicating a need to streamline the permit application process. The time required for 
public notice of a hearing to promulgate any water quality standard or regulation is reduced from 60 to 45 days. The time allowed for public comment on a permit application is also reduced from 45 to 30 days. Additionally, the bill limits the time period in which a person suspected of violating any permit or control regulation may request samples of water pollutants.

Bill 3 clarifies that the Department of Health may not grant a variance from permit limitations unless it is authorized by the federal Clean Water Act. Finally, the bill authorizes criminal penalties for any person who recklessly, knowingly, intentionally, or with criminal negligence discharges pollutants into any state waters in violation of any pretreatment regulations of the Water Quality Control Commission.

\section{Bill 4 - Concerning Water Quality Control Permits System Fees}

Bill 4 reauthorizes the annual fee levied for a permit to discharge pollutants into state waters. The bill provides that the current statutory categories and fee schedule be continued through fiscal year 1992-93. The committee expressed concern that any changes in categories or substantial increases in permit fees based on a total cash-funded program may adversely affect the regulated community. The present fee schedule will expire June 30, 1988, without statutory reauthorization.

\section{Water Quality Authority}

Bill 5 -- Concerning the Creation of the Cherry Creek Bas in Water Quality Authority

Due to increasing levels of phosphorous found in the Cherry Creek Reservoir, local governmental agencies recently formed an authority to maintain water quality in the Cherry Creek Reservoir. The authority relies solely on dues paid by members to meet its costs. Without a statutory financing mechanism, the authority cannot receive federal fund's.

Bill 5 creates the Cherry Creek Basin Water Quality Authority and defines its boundaries. Powers and duties of the authority include conducting pilot studies for potential water quality control solutions, implementing programs to provide incentives for water quality control projects, recommending the maximum loads of pollutants allowable to maintain certain standards, recommending erosion controls and urban runoff control standards, and exercising the power of eminent domain with, respect to rights-of-way and sites for drainage and nonpoint source or runoff water quality control facilities. The authority may issue bonds and levy property taxes of no more than two mills per year on assessed valuation in its boundaries. 


\section{Chemigation}

Bi11 6 -- Concerning Amendments to the "Colorado Chemigation Act", and Relating to the Definitions of "Chemigation" and "Irrigation", an Increase in the Permit and Inspection Fees, and the Penalties Provided for Violations of the Act

Chemigation refers to an agricultural practice that uses irrigation water as a transport mechanism for the application of chemicals to soils and crops. Of greatest concern is the potential for direct aquifer contamination if the irrigation mixture of water and chemicals should backflow down the water supply well.

Under the 1987 Colorado Chemigation Act, the definition of "chemigation" is limited to wells greater than two inches in diameter and that have a well permit from the state engineer. Bill 6 expands the definition of chemigation to include any process whereby chemicals are applied to land or crops in or with water through an irrigation system. The definition of "irrigation" is enlarged to include any device or combination of devices having a hose, pipe, or other conduit which connects directly to any source of groundwater or surface water.

Bill 6 increases the provisional chemigation and chemigation permit fee to $\$ 100$ but limits the inspection fee to $\$ 80$. The penalty for violation of the act is reduced from a class 5 felony to a misdemeanor to provide a more realistic enforceable penalty.

\section{Meeting Colorado's Interstate Compact Requirements}

Bill 7 -- Concerning an Appropriation to the Department of Natural Resources for Allocation to the State Engineer

The United States Bureau of Reclamation will cease accounting for water stored and delivered from Green Mountain Reservoir and water delivered for transmountain diversions from the Colorado River Basin. In order to maintain an accurate record of water deliveries required by the Colorado River Compact, the state must assume the function. For purposes of administering the state's water compacts, Bill 7 provides an appropriation for additional staff to the office of the State Engineer

\section{Authorization of Water Projects}

Bill 8 -- Concerning Projects Funded by the Colorado Water Conservation Board Construction Fund, and Relating to the Activities of the Colorado Water Conservation Board in Connection Therewith

Bill 8 autnorizes financial assistance loans to water resource projects out of the Colorado Water Conservation Board Construction 
Fund. This fund provides low interest loans for one-half of a water project's cost, after projects have been authorized by the Colorado General Assembly. These low interest loans are for projects which increase the beneficial consumptive use of Colorado's compact entitled waters or for projects which repair and rehabilitate existing water storage and delivery systems.

\section{Dredge and Fill Permit}

Joint Resolution A -- Requesting That the United States Army Corps of Engineers Consolidate Their District Boundaries in Colorado

This resolution requests that the United States Army Corps of Engineers consolidate its five district boundaries for the state into one district and continue to maintain a district office in the state. The district offices of the Corps that have jurisdiction in Colorado are located in Albuquerque, Kansas City, Omaha, Sacramento, and Tulsa. Multiple districts oftentimes cause confusion as to which district office applicants for 404 dredge and fill permits must contact. Also situations are created in which similar projects are subject to different interpretations of rules and regulations by different districts.

\section{Other Committee Activities}

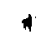

The committee studied the impact that transmountain diversions have on deterioration of water quality in the basin of diversion by examining the experiences of Grand and Summit counties. The committee also received a briefing on the status of the water Rights Determination Study which was authorized by Senate Bill 15, 1987 legislative session, and an overview of the state's groundwater quality protection plan. The committee did not make any recommendations on these topics. 


\section{BACKGROUND REPORT}

\section{Protection of Drinking Water}

Under the 1986 amendments to the federal Safe Drinking Water Act, the Environmental Protection Agency (EPA) is required to establish regulations by 1989 for more than 80 contaminants found in drinking water. Currently, 25 contaminant levels are regulated. As a result, the EPA has significantly increased its drinking water standards setting activities with regard to revisions of old standards as well as establishing standards of unregulated contaminants. Essentially the amendments require stricter monitoring and sampling of drinking water, the setting of additional primary standards, specifying criteria for filtration of surface water supplies, and disinfection of surface and groundwater supplies. Every public water supply in the nation must meet these primary drinking water standards.

Testimony to the committee revealed that Colorado's existing standards appear to be effective in the specific areas presently covered. Representatives of the Division of Water Quality Control said that very few waterborne disease outbreaks occur in the state and there have been no long-term health effects identified in Colorado associated with any of the chemical contaminants for which standards have been set.

However, a primary concern of the Department of Health is being able to set a standard for contaminants that are not covered by federal law. Certain drinking water contamination problems have involved chemicals for which no federal standards have been set (such as tricholoroethylene and plutonium). Current state law forbids more stringent regulation of contaminants than those imposed by the federal government, which means the state cannot regulate contaminants for which no federal standards presently exist.

For example, hydrazine, a by-product of rocket fuel has been identified in the groundwater but has not been found in a water system as yet. Hydrazine is estimated to be 1,000 times more carcinogenic than the tricholoroethylene found in the wells contaminated by the Rocky Mountain Arsenal. Because hydrazine is a "localized" problem, as opposed to a "national" problem, primary standards will not be set for this contaminant by the EPA and the state could not set a standard for hydrazine should it be discovered in a water supply.

Recommendations. The committee recommends that the State Board of Health be authorized to set additional standards for carcinogenic, mutagenic, tetragenic, and toxic contaminants found in a water source. Bill I has three major sections which are described in the following paragraphs.

Annual priority list. The bill requires the Colorado Department of Health to establish and revise annually a priority list of contaminants for which standards may be considered. The priority list 
must be prepared according to a ranking process incorporating the following considerations:

-- the actual presence of a contaminant in a drinking water supply or the relative imminence of a threat of contamination of a drinking water supply;

-- the identifiability of a potential pathway of contamination;

-- the availability of analytical techniques for measuring and identifying the contaminant in a reasonable manner;

-- sufficient information concerning the contaminant to allow an appropriate standard to be developed;

-- the magnitude of potential health risks of the contaminant at reasonably anticipated exposure levels;

-- the fact that the contaminant will be the subject of a national primary drinking water regulation in the near future; and

-- the level of effort and scope of work that will be necessary to develop sufficient data for the purpose of supporting an appropriate standard.

This priority list is submitted to the State Board of Health for review and approval.

Standard setting. The board may adopt minimum general sanitary standards for contaminants not addressed by federal law. Industry representatives expressed concern that state standards should be scientifically based, documented, and arrived at in a scientific manner. In short, the bill requires that a specific process be followed in determining standards.

The Board of Health must find that before any additional standards are contemplated: 1) the standards are adequate to protect public health and have a demonstrated medical, technological, and scientific basis; 2) based on credible medical and toxicological evidence that has been subjected to peer review, there exists a substantial risk to the public health; 3) the analytical techniques for measuring and identifying the contaminant are reasonably available; 4) the adverse health effects posed by the contaminant are known to a reasonable degree of scientific certainty; and 5) compliance with the standard is feasible utilizing the best technology or methodology which is generally available. Finally, if the department intends to recommend standards to the board, the severity of the risks involved must be assessed.

The Department of Health is to maintain a laboratory certification program to ensure competent testing of drinking water laboratories that 
test drinking water. This provision assures that sufficient qualified laboratory facilities exist to meet the demands of public water suppliers on a timely basis.

Enforcement. Bill 1 allows local water suppliers and the Colorado Department of Health a cause of action against anyone, including the federal government, who contaminates the water which purveyors supply to the public. Current law allows the Colorado Department of Health to enforce drinking water standards only against public water suppliers, not against the source of pollution.

The bill authorizes water suppliers or the department to bring suit to prevent or to mitigate a release or imminent release of contaminants which would result in either a violation of a minimum general sanitary standard or would render a public drinking water supply unfit for human consumption. Costs of providing an interim substitute drinking water supply are to be borne by the owner or operator of the source from which the contaminants occur.

\section{State Water Pollution Control Revolving Fund}

Also with regard to maintaining water quality, the committee reviewed impacts that amendments to the Federal Clean Water Act may have on financing wastewater treatment facilities. One important requirement of the act is that states create a water pollution control revolving fund to provide assistance to municipalities and state agencies for construction of publicly owned wastewater treatment plants. A program must be in place by October 1,1988 . The federal amendments further authorize the use of construction grant moneys in fiscal year 1988 and 1989 to capitalize the revolving fund. This method of capitalization gradually phases the current federal grants program into a loan program designed to meet the state's future wastewater treatment needs.

All federal money for financing treatment facilities will end in 1994. The state must match the federal portion of the revolving fund with 20 percent cash, so that $\$ 200,000$ of state money must be deposited in the fund for each $\$ 1$ million granted by the federal government. Since 1956, the Division of Water Quality Control has administered 460 federal grants for wastewater treatment facilities totaling $\$ 315$ million. The division estimates that the 55 entities on the 1988 Construction Grants State Project Priority List need an estimated $\$ 137.5$ million. The committee recommends Bill 2, which creates a revolving fund for water pollution control, thus allowing the state to take full advantage of the changes in the federal program. Colorado's expected federal grants and maximum capitalization possible in the revolving fund for the next seven years, are as follows: 
Estimated Maximum Capitalization for Revolving Fund 1 /

(\$ in millions)

\begin{tabular}{|c|c|c|c|c|}
\hline Year & $\begin{array}{c}\text { Federal } \\
\text { Contribution } \\
\end{array}$ & $\underline{\text { SRF }}$ & $\begin{array}{l}\text { State } \\
\text { Match }\end{array}$ & Total \\
\hline $\begin{array}{ll}\text { FY } & 88 \\
\text { FY } & 89 \\
\text { FY } & 90 \\
\text { FY } & 91 \\
\text { FY } & 92 \\
\text { FY } & 93 \\
\text { FY } & 94\end{array}$ & $\begin{array}{r}\$ 19.4 \\
19.4 \\
19.4 \\
19.4 \\
14.6 \\
9.7 \\
4.9\end{array}$ & $\begin{array}{r}\$ 14.5 \text { 2/ } \\
19.4 \text { I/ } \\
19.4 \\
19.4 \\
14.6 \\
9.7 \\
4.9\end{array}$ & $\begin{array}{l}\$ 2.9 \\
3.88 \\
3.88 \\
3.88 \\
2.9 \\
1.94 \\
.98\end{array}$ & $\begin{array}{r}\$ 17.4 \\
40.68 \\
63.96 \\
87.24 \\
104.74 \\
116.38 \\
122.26\end{array}$ \\
\hline
\end{tabular}

The bill is designed so the state manages the fund for local governments and provides these governments with the best possible financing package using a variety of financing mechanisms. The bill coordinates the water quality expertise of the Division of Water Quality Control, assistance provided to local governments by the Division of Local Government to obtain federal and state loans, and the bonding and management capability of the Colorado Water Resources and Power Development Authority.

The Division of Water Quality Control is the primary contact agency for the EPA and loan applicants and ensures that projects conform to the provisions of the "Colorado Water Quality Control Act". The Division of Local Government is to assist local governments in acquiring the best financing package available and approve all loan terms and conditions. The Colorado Water Resources and Power Development Authority has the final determination for issuing loans and is to manage the fund.

All three agencies are to develop an intended use plan that is to enumerate bonds the authority needs to issue, the amounts and conditions of the bonds, a list of loans to be made, including terms and conditions, and the interest and repayment schedules. Thus, a partnership has been established whereby each agency has specific responsibilities and authority individually, and all three have some joint responsibility.

1/ Source: Division of Local Government, 1987.

2/ Maximum amount used to capitalize the fund has not been decided. 
Amendments to the Water Qual ity Control Act

The committee discussed the desirability of continuing a full state water quality control program in view of criticism by the federal government. During the last few years, there have been a number of disputes between Colorado and the EPA regarding whether state laws, rules and regulations, and the implementation of the state's water quality program are consistent with the requirements of federal laws and EPA policies. A major dispute concerns the degree of flexibility in granting permits accorded the state by the EPA in implementing the state's water quality program.

Under delegation agreements with the EPA, the state is responsible for the implementation of various water quality programs. The goals are to eliminate dual federal and state regulation, to better address regional and local water quality problems, and to tailor a program to Colorado's arid climate and unique water rights system. The state has full authority to manage the permit issuance activity, to assure all permits for industrial and municipal dischargers are issued in a timely manner, and to meet applicable state and EPA requirements. The EPA, under federal law and its agreement with the state, oversees state programs so as to assure compliance with the minimum federal requirements.

Members of the regulated community testified that EPA has vetoed a number of state-issued discharge permits and has instead issued its own permits. This has resulted in dual permitting and increased expense and effort on the part of the state and the regulated community. In addition, there have been separate and parallel enforcement actions taken on discharge permit violations by the EPA and the state. Dual enforcement actions result in increased administrative time and cost for governmental agencies and the groups subject to regulation.

The EPA regional administrator defended the EPA's attempt to provide fair and consistent regulation of the act and oversight. The EPA has objected to only ten proposed state permits since 1984, and eventually issued only two federal permits. In general, the regulated community supports the state's authority to administer the permit program. There are several advantages in retaining the state permit program: 1) it would keep regulation and decision making closer to the problem, as state agencies tend to be more familiar with local issues and more readily accessible to permittees; 2 ) the state has a better understanding of the relationship between water quality requirements and the state's water rights system; 3 ) interest groups in Colorado have a greater opportunity for involvement in the development of program regulations and related rule-making; 4) state enforcement mechanisms are not as burdensome as EPA's; 5) the state would maintain control over all water quality program functions including water quality standards, planning, construction grants, monitoring, and enforcement; and 6) the state would not experience the loss of federal funds. No recommendation is submitted on withdrawing the state from the permit program. 
One of the committee's charges related to coordination of the activities of various state agencies responsible for water issues. Towards this end, the committee invited the regulated community and state and local agencies to identify problems and areas of duplication in the permit system. Problems identified involved the length of time to obtain permits, the costs involved, and the interpretation of the federal "Endangered Species Act" in delaying the process. Several recommendations outlined in the following paragraphs are made for improving the permitting process.

Time notice change. To expedite the issuance of permits, Bill 3 decreases the required time for public notice of a hearing to promulgate rules and regulations (from 60 to 45 days) and reduces the time for public comment on a permit application from (45 to 30 days). A recent performance audit of the Water Quality Control Division indicated that the 45 day comment period on permits contributed to delays in getting permits issued within 180 days as required by statute. The public notice period needs to be shortened to 30 days to facilitate meeting the 180-day deadline.

Further, the bill limits the time to six months after collection for a person who is suspected of violating any permit or control regulation to request a sample of water or water pollutants. The addition of the qualifying language will relieve the water Quality Control Division of the need to both deliver a split sample to a discharger and to store a sample for an excessive time waiting for a request for a sample. The bill also clarifies the division's inability to grant variances from any feder ll requirement or from a standardsbased limit, unless it is authorized by the federal Clean water Act. Lastly, the bill imposes criminal penalties for any person who recklessly, knowingly, intentionally, or with criminal negligence discharges pollutants into any state waters in violation of any pretreatment regulations promulgated by the Water Quality Control Commission.

Permit system fees. Bill 4 reauthorizes the annual fee levied on a discharger for a permit to discharge pollutants into state waters. The current statutory categories and fee schedule are continued through fiscal year 1992-93. Concern was expressed that any changes in categories or substantial increases in permit fees, based on a total cash-funded program, may adversely affect the regulated community. The present fee schedule expires June 30, 1988, without statutory reauthorization.

\section{Cherry Creek Basin Water Quality Authority}

Cherry Creek Reservoir is a mildly eutrophic plains reservoir which has limited outlets. Its water quality is adequate for the classified uses at present. However, acceleration of eutrophication resulting from projected population growth could cause harm to recreation and aquatic life uses. Most of the pollutants entering the reservoir, such as phosphorus, come from non-point sources via surface 
drainages. The Colorado Water Quality Control Commission has set phosphorous and chlorophyll standards for Cherry Creek Reservoir to stop the lake's pollution, thereby protecting the reservoir's recreational use and aquatic life.

Local governmental agencies in the basin have established by intergovernmental agreement the Cherry Creek Basin Water Quality Authority to maintain water quality in the Cherry Creek Basin. The authority is comprised of members such as the cities of Castle Rock, Parker, Aurora, the Arapahoe Water and Sanitation District, Denver Southeast Suburban Water and Sanitation District, and the Meridian Metropolitan District. The authority monitors the lake's phosphorous levels and has developed a strategy for resolving the problem by recommending practices, policies, and incentive programs to local entities.

The authority relies solely on dues paid by members to meet its costs. Without a statutory financing mechanism, the authority cannot receive federal funds. Under $B i 115$, the authority may issue bonds and levy property taxes of no more than two mills per year on assessed valuation within its boundaries which are defined in the bill. Powers and duties of the authority include conducting pilot studies for potential water quality control solutions, implementing programs to provide incentives for water quality control projects, recommending the maximum loads of pollutants allowable to maintain certain standards, and recommending erosion controls and urban runoff control standards. The Cherry Creek Basin Water Quality Authority is an example of a unified approach to the protection of water quality.

\section{Amendments to the "Colorado Chemigation Act"}

The Colorado Chemigation Act was enacted in 1987. Chemigation refers to an agricultural practice that uses irrigation water as a transport mechanism for the application of chemicals to soils and crops. The practice of chemigation has increased during recent years due primarily to increased energy costs and advancements in irrigation system design. Of greatest concern is the potential for direct aquifer contamination if the irrigation mixture of water and chemicals should backflow down the water supply well. This poses a serious health risk to the irrigator, given that most irrigation wells are drilled into the same aquifer that supplies the household and domestic water needs of the agricultural community.

Bill 6 expands the definition of "chemigation" to include any process whereby chemicals are applied to land or crops in or with water through a closed irrigation system. Also enlarged is the definition of "irrigation" which includes any device or combination of devices having a hose, pipe, or other conduit which connects directly to any source of groundwater or surface water. The bill increases the provisional chemigation and chemigation permit fee to $\$ 100$ but limits the inspection fee to $\$ 80$. The penalty for violation of the act is reduced 
from a class 5 felony to a misdemeanor to provide a more realistic enforceable penalty.

\section{Meeting Colorado's Interstate Compact Requirements}

Representatives from state agencies and legal counsel retained by the General Assembly provided an update on Colorado's interstate compact agreements. Overall, the state is meeting its compact requirements on the Colorado, Rio Grande, Republican, and South Platte Rivers. According to a spokesman from the Colorado Water Conservation Board, the Colorado River has an estimated one million acre feet of unused compact water allocated to the state. The water debt owed to New Mexico and Texas on the Rio Grande River was erased when water deliveries spilled on Elephant Butte Reservoir.

A new Special Master has been appointed in the Colorado/Kansas litigation over the Arkansas River Compact which could increase the state's share of costs in the lawsuit. A spokesperson of the Attorney General's office said that the state may also be involved in litigation concerning the North Platte River. Litigation has arisen involving Wyoming, Nebraska, and groups defending wildlife protected by the Endangered Species Act. Colorado is currently monitoring this litigation and has filed arguments against the petitioners in conjunction with Wyoming. In addition, the State Engineer said that litigation involving the interpretation of the Endangered Species Act may also arise over future development of unused compact water.

Finally, the Bureau of Reclamation will soon cease to do the accounting for water stored in and delivered from Green Mountain Reservoir and water delivered for transmountain diversions out of the Colorado River Basin. Bill 7 makes an appropriation for additional staff to the Office of the State Engineer to assume this function.

\section{Water Project Authorization}

With regard to management and development of our surface water resources, the committee recommends $B i 11$ 8. The bill authorizes approval of financial assistance loans to water resource projects out of the Colorado Water Conservation Board Construction Fund. This fund provides low interest loans for one-half of a water project's cost, after projects have been authorized by the General Assembly. Recipients of these low interest loans are projects which increase the beneficial consumptive use of Colorado's compact ent itled waters or projects which repair and rehabilitate existing water storage and delivery systems. These water resource projects are reviewed and recommended by the Colorado Water Conservation Board to the General Assembly in January. 
404 Dredge and Fill Permit

Consideration was given to state assumption of the 404 permit program for discharge of dredge or fill material into state regulated waters. Section 404 of the Federal Clean Water Act provides that most discharges of dredged or fill materials into a waterway or wetland require a permit issued by the United States Army Corps of Engineers. Section 404 also allows states desiring to obtain the suspension of the issuance of permits by the Corps to apply for such suspension. In this manner a state may assume the sole responsibility for regulating the disposal of dredge or fill materials into the navigable waters within its jurisdiction. However, the Federal Clean Water Act and regulations pursuant to Section 404 set forth a number of requirements which must be satisfied by a state before it may qualify for the 404 permit assumption.

Proponents of state assumption argued that the state is a closer, more directly responsible political entity to the citizen applicant. The state agency responsible for administering the program would be more aware of local issues and concerns and therefore, more responsive to the impacts of permit decisions.

Frustration with dealing with the five district Corps of Engineer offices was also expressed. The district offices of the Corps that have jurisdiction in Colorado are located in Albuquerque, Kansas City, Omaha, Sacramento, and Tulsa. Permit applicants pointed to inconsistencies of the different corps districts in administering the program. Multiple districts oftentimes cause confusion as to which district office applicants must contact, and create situations where similar projects are subject to different interpretations of rules and regulations by different districts. Costly delays due to the distance from Colorado to district corps offices are also created. State assumption, it was suggested, would eliminate much of this inconsistency, and make it easier and less expensive for applicants who will have fewer agencies to deal with.

After examining the cost of funding the program, the degree of federal oversight, and the benefits the state would receive by assuming the program, the committee decided not to pursue this matter. However, Joint Resolution $A$ is recommended requesting that the Corps of Engineers consolidate its five district boundaries for the state into one district and maintain a district office in the state.

\section{Effect of Transmountain Diversion on Water Quality}

In order to gain an understanding of the impact of transmountain diversions on water quality, the committee examined the effect of diversions experienced in Grand and Summit count ies. The combination of transmountain diversions occurring high in the watershed and water quality regulations have severely limited Grand County's ability to grow. Grand County officials testified that to develop some of the 22,000 acres of land in the county a person must provide 20 times the 
water required in order to meet state and federal standards. For example, the cost of purchasing 96 acre feet of water is approximately $\$ 375,000$, but the county's water needs to meet these standards are much higher. Developing alternative water supplies is also costly and difficult.

Summit County officials were concerned with transported hazardous materials being spilled in the watershed and the increasing phosphorous levels in Lake Dillon. Also mentioned were problems of the economic and environmental impacts of future transmountain diversions above Lake Dillon which may reduce the stream flows between Lake Dillon and Green Mountain Reservoir. The county has concentrated on reducing the phosphorous levels in the lake through its land use powers, erosion control programs, and the consolidation of sewage treatment plants to reduce lake pollution.

\section{Water Rights Determination Study}

Section 4 of Senate Bill 15, 1987 session, directed the Colorado Water Conservation Board to study Colorado's water rights system together with the systems employed in other western states. A representative of the board informed the committee that a draft of the proposed study has been mailed to over 1,000 interested persons. The draft study poses the following questions.

1) Is the current system of managing Colorado water resources too costly and time consuming?

2) Is the water managed by the system used in the most efficient manner possible?

3) How are water quality and water quantity issues integrated?

After it receives and assesses public comments, the board will discuss a revised version of the proposal. Statute also provides that the board cannot proceed until its request for proposals is approved by the Legislative Council.

\section{Groundwater Quality Protection Program}

Members of the Water Quality Control Commission briefed the committee on the development of a state groundwater quality protection program. The commission has adopted an overall goal:

"to provide maximum beneficial use of groundwater resources, while assuring the safety of the users by preventing or controlling those activities which have the potential to impair existing or future beneficial uses of groundwater or to adversely affect the public health." 
The commission has determined that any new control regulations should be designed to fill gaps in existing programs, rather than to create a new blanket program that would likely result in duplication and inconsistencies with existing programs. 


\title{
BILL 1
}

\author{
A BILL FOR AN ACT \\ CONCERNING THE PROTECTION OF DRINKING WATER, AND, IN \\ CONNECTION THEREWITH, CONFORMING THE STATE DRINKING WATER \\ PROTECTION PROVISIONS TO THE REQUIREMENTS OF THE 1986 \\ AMENDMENTS TO THE FEDERAL "SAFE DRINKING WATER ACT", \\ ADOPTING MINIMUM GENERAL SANITARY STANDARDS FOR DRINKING \\ WATER IN THE ABSENCE OF FEDERALLY PROMULGATED STANDARDS, \\ ESTABLISHING A LABORATORY CERTIFICATION PROGRAM, AND \\ PROVIDING FOR THE ENFORCEMENT OF DRINKING WATER STANDARDS \\ AND PROTECTION OF DRINKING WATER SUPPLIES.
}

\section{Bill Summary}

(Note: This summary applies to this bill as introduced and does not necessarily reflect any amendments which may be subsequent ly adopted.)

Conforms the drinking water protection statutes with the requirements of amendments to the federal "Safe Drinking Water Act". Provides that minimum general sanitary standards adopted by the department of health are reasonab", consistent with the protection of public health and welfare. Requires that water quality standards for water supplied to the public must, at a minimum, be consistent with existing federal standards or, if no federal standards exist, allows the department of health to adopt its own such standards. Provides for enforcement of drinking water standards and protection of drinking water supplies. Establishes a laboratory certffication program for laboratories which test 
drinking water.

Be it enacted by the General Assembly of the State of Colorado: SECTION 1. 25-1-107 (1) (x) (I) and (2), Colorado Revised Statutes, 1982 Repl. Vol., are amended, and the said 25-1-107 (1) ( $x$ ) is further amended BY THE ADDITION OF A NEW SUBPARAGRAPH, to read:

25-1-107. Powers and duties of the department. (1) (x) (I) To adopt and enforce minimum general sanitary standards and regulations to protect the quality of drinking water supplied to the public, including the authority to require disinfection AND TREATMENT of such water. WHEN THE LABORATORY ANALYSIS OF A WATER SUPPLY HAS CONSISTENTLY SHOWN THAT THE WATER MEETS ALL APPLICABLE STANDAROS AND HAS MET SUCH STANDARDS FOR A PERIOD OF FIVE YEARS, THE DEPARTMENT MAY NOT REQUIRE ADDITIONAL TREATMENT OR DISINFECTION OF THE SUPPLY, UNLESS THE DEPARTMENT CAN DEMONSTRATE BEYOND A REASONABLE DOUBT THAT THE QUALITY OF THE WATER WILL DETERIORATE.

(VIII) (A) Any political subdivision of the state which stores, releases, carries, conveys, supplies, or treats water for use by or in a public drinking water supply system or the department may bring suit for injunctive relief, in addition to all remedies otherwise available, to prevent or abate any release or imminent release of contaminants which results or would result in a violation of any minimum general sanitary standard or regulation adopted pursuant to this section or which interferes or would interfere with the treatment 
capability of a water treatment system or renders or would render the system's drinking water supply unfit for human consumption. Such an action may be maintained against the owner or operator of the source or sources of the release of the contaminants, but no such action may be maintained with regard to surface or underground agricultural return flows except as otherwise provided in the "Colorado Chemigation Act", article 11 of title 35, C.R.S. The costs of any remedy ordered or approved by the court, including, as necessary, the costs of providing an interim substitute drinking water supply, shall be borne by the owner or operator of the source or sources from which the release of contaminants is occurring or is threatened to occur.

(B) Any person who has resolved his liability to the state or to a supplier of drinking water under this subparagraph (VIII) in a judicially approved settlement shall not be liable for claims for contribution regarding matters addressed in the settlement. Such settlement does not discharge any of the other potentially liable persons unless the terms of the settlement so provide.

(C) Nothing in this paragraph $(x)$ shall be construed to restrict or preempt any right which the state, the department, any public water system, or any other person may have under any other law to seek enforcement, in any court or in any administrative proceeding, of any provision of this paragraph $(x)$ or any other relief regarding contamination of any drinking water supply. In addition, nothing in this paragraph 
(x) shall be construed to condition, restrict, or prevent any other civil or criminal actions which may be brought by the state or any political subdivision pursuant to any other state or federal statute or regulation or any local ordinance or regulation.

(2) (a) The phrase "minimum general sanitary standards" as used in this section and section 25-1-109 (1) (h) means the minimum standards reasonably consistent with ASSURING ADEQUATE protection of the public health, and, in the case of minimum general sanitary standards as to the quality of water supplied

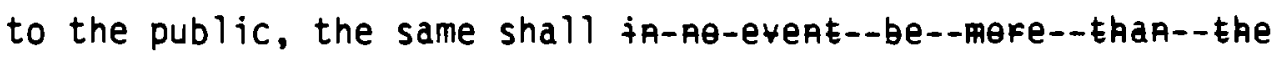
GFiaking--watef--standafes-premutgated-pufsuaht-te-the-federat "safe--dfiakiag--watef--atŁ" BE ESTABLISHED BY RULE AND REGULATION AND SHALL BE APPROPRIATE TO PROMOTE AND PROTECT THE PUBLIC HEALTH FROM ENDANGERMENT PRESENTED BY CARCINOGENIC, MUTAGENIC, TERATOGENIC, OR TOXIC CONTAMINANTS OR SUBSTANCES. SUCH STANDARDS SHALL BE BASED ON THE BEST AVAILABLE ENDANGERMENT ASSESSMENT EVIDENCE AND THE BEST AVAILABLE TREATMENT TECHNOLOGY OR METHODOLOGY. The word "standards" as used in this section and section 25-1-109 (1) (h) means standards reasonably designed to promote and protect the public health.

(b) MINIMUM GENERAL SANITARY STANDARDS FOR THE QUALITY OF WATER SUPPLIED TO THE PUBLIC SHALL BE NO MORE STRINGENT THAN THE DRINKING WATER STANDARDS PROMULGATED PURSUANT TO THE FEDERAL "SAFE DRINKING WATER ACT", IF SUCH STANDARDS EXIST. IF NO STANDARDS hAVE BEEN PROMULGATED PURSUANT TO THE FEDERAL 
"SAFE DRINKING WATER ACT" REGARDING THE PERMISSIBLE CONCENTRATION OF ANY CONTAMINANT OR ANY SUBSTANCE IN DRINKING WATER, THE DEPARTMENT MAY RECOMMEND TO THE BOARD FOR PROMULGATION MINIMUM GENERAL SANITARY STANDARDS REGARDING SUCH CONTAMINANT OR SUBSTANCE.

(c) (I) THE DEPARTMENT SHALL ANNUALLY ESTABLISH AND REVISE A PRIORITY LIST OF CONTAMINANTS OR SUBSTANCES FOR WHICH STANDARDS MAY BE CONSIDERED AND SHALL SUBMIT SAID LIST TO THE BOARD FOR REVIEW AND APPROVAL.

(II) THE PRIORITY LIST OF CONTAMINANTS OR SUBSTANCES, TOGETHER WITH THE DEPARTMENT'S EVALUATION OF THE CONSIDERATIONS LISTED IN THIS SUBPARAGRAPH (II), SHALL BE SUBMITTED TO THE BOARD FOR REVIEW AND APPROVAL. THE PRIORITY LIST SHALL BE PREPARED ACCORDING TO A RANKING PROCESS WHICH INCORPORATES THE FOLLOWING CONSIDERATIONS:

(A) THE ACTUAL PRESENCE OF A CONTAMINANT OR SUBSTANCE IN A DRINKING WATER SUPPLY SYSTEM OR THE RELATIVE IMMINENCE OF THREAT OF CONTAMINATION OF A DRINKING WATER SUPPLY SOURCE;

(B) THE IDENTIFIABILITY OF A POTENTIAL PATHWAY OR CONTINUED PATHWAY OF CONTAMINATION;

(C) THE AVAILABILITY OF ANALYTICAL TECHNIQUES FOR MEASURING AND IDENTIFYING THE CONTAMINANT IN A REASONABLE MANNER;

(D) SUFFICIENT AVAILABLE INFORMATION CONCERNING THE CONTAMINANT OR SUBSTANCE TO ALLOW AN APPROPRIATE STANDARD TO BE DEVELOPED, INCLUDING INFORMATION ON THE HEALTH EFFECTS OF THE CONTAMINANT OR SUBSTANCE AS WELL AS AVAILABLE TREATMENT 
TECHNOLOGY;

(E) THE MAgNITUDE OF POTENTIAL hEALTH RISKS OF THE CONTAMINANT OR SUBSTANCE AT REASONABLY ANTICIPATED EXPOSURE LEVELS;

(F) THE FACt that the CONTAMInANT OR SUbStance WILL BE THE SUBJECT OF A NATIONAL PRIMARY DRINKING WATER REGULATION IN THE NEAR FUTURE; AND

(G) THE LEVEL OF EFFORT AND SCOPE OF WORK THAT WILL BE NECESSARY TO DEVELOP SUFFICIENT DATA FOR THE PURPOSE OF SUPPORTING AN APPROPRIATE STANDARD.

(d) (I) FOLLOWING THE DEPARTMENT'S SUBMISSION OF RECOMMENDED STANDARDS TO THE BOARD, THE BOARD MAY PROMULGATE STANDARDS FOR CONTAMINANTS OR SUBSTANCES THAT ARE NOT THE SUBJECT OF A STANDARD SET PURSUANT TO THE FEDERAL "SAFE DRINKING WATER ACT".

(II) IN THE PROMULGATION OF SUCH STANDARDS, THE BOARD SHALL FIND THAT THE STANDARDS ARE ADEQUATE TO PROTECT PUBLIC heALTH AND haVe a DEMONSTRATED medical, teChNOLOGicAl, and SCIENTIFIC BASIS AND THAT:

(A) BASED ON CREDIBLE MEDICAL AND TOXICOLOGICAL EVIDENCE THAT HAS BEEN SUBJECTED TO PEER REVIEW, THERE EXISTS A SUBSTANTIAL RISK TO THE PUBLIC HEALTH;

(B) THE ANALYTICAL TECHNIQUES FOR MEASURING AND IDENTIFYING THE CONTAMINANT OR SUBSTANCE ARE REASONABLY AVAILABLE;

(C) THE ADVERSE hEALTH EFFECTS POSED BY tHE CONTAMINANT OR SUBSTANCE ARE KNOWN TO A REASONABLE DEGREE OF SCIENTIFIC 


\section{CERTAINTY; AND}

(D) COMPLIANCE WITH SUCH STANDARD IS FEASIBLE UTILIZING THE BEST TECHNOLOGY OR METHODOLOGY WHICH IS GENERALLY AVAILABLE.

(e) IN THE EVENT THE DEPARTMENT INTENDS TO RECOMMEND STANDAROS TO THE BOARO, THE DEPARTMENT SHALL PREPARE AN ENDANGERMENT ASSESSMENT.

SECTION 2. 25-1-107 (1), Colorado Revised Statutes, 1982 Repl. Vol., as amended, is amended BY THE ADOITION OF A NEW PARAGRAPH to read:

25-1-107. Powers and duties of the department. (1) (x.5) (I) To establish and maintain a laboratory certification program for the purpose of ensuring competent testing of drinking water as required by the federal "Safe Orinking Water Act" and subsection (2) of this section. Certification procedures shall, at a minimum, include water supply evaluation verification and on-site inspections. The laboratory certification program shall consist of certification levels which correspond to the testing capability and capacity of each laboratory. In addition to certifying laboratories for contaminants regulated as of the effective date of this paragraph (x.5) the department shall adopt and implement a schedule for certifying sufficient laboratory capacity for the testing and analysis of contaminants for which reference methods are available and which are scheduled to be regulated under the federal "Safe Drinking Water Act". 
(II) Upon request, the department shall refer a public water supplier to a laboratory, either the department's or one certified by the department, which is determined to be equipped to perform the required testing and analysis on a timely basis.

(III) To facilitate an effective laboratory certification program, the department shall work with local public water suppliers toward creating and maintaining a centralized data base which:

(A) Quantifies the current and expected demands for the monitoring, testing, and analysis of each supplier, grouped according to the size of the supply system, the source of its supply, and the requirements imposed on each supplier;

(B) Includes an updated list of laboratories certified and available for the testing and analysis of specific contaminants; and

(C) Tracks violations of drinking water standards for the purpose of facilitating an exchange among public water suppliers in addressing similar problems posed by specific contaminants.

SECTION 3. 25-1-114.1 (3), Colorado Revised Statutes, 1982 Repl. Vol., as amended, is amended, and the said 25-1-114.1 is further amended BY THE ADDITION OF A NEW SUBSECTION, to read:

25-1-114.1. Civil penalties. (3) The division--of admiatstration DEPARTMENT may request the attorney general to bring a suit for a temporary restraining order $O R \quad A$ 
PRELIMINARY or permanent injunction to prevent or abate any violation of a minimum general sanitary standard or regulation adopted pursuant to section 25-1-107 (1) ( $x$ ) OR TO PREVENT OR ABATE ANY CONDITION OR ACTIVITY THAT CAUSES OR IS LIKELY TO CAUSE CONTAMINATION RESULTING IN LIABILITY UNDER SECTION 25-1-107 (1) (x) (VIII). The diyisier--ef-admiatstabtien DEPARTMENT is not required to issue an enforcement order prior to institution of such a suit. Upon A finding that such a violation has occurred, IS OCCURRING, or is about to occur aAd

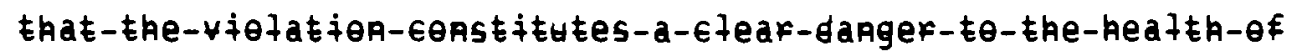
any--pefser, OR THAT SUCH CONDITION OR ACTIVITY EXISTS, the court shall ENJOIN SUCH VIOLATION, CONDITION, OR ACTIVITY AND enter such order as the public health may require, taking into consideration, where appropriate, the cost and time necessary to comply.

(4.5) An action for civil penalties under this section may be joined with a civil action to recover the state's costs pursuant to section 25-1-107 (1) (x) (VIII).

SECTION 4. Safety clause. The general assembly hereby finds, determines, and declares that this act is necessary for the immediate preservation of the public peace, health, and safety. 
BILL 2

A BILL FOR AN ACT

1 CONCERNING AUTHORIZATION FOR THE STATE TO PARTICIPATE IN THE WATER POLLUTION CONTROL REVOLVING FUND CREATED BY THE FEDERAL "WATER QUALITY ACT OF 1987" BY PROVIDING FOR THE CREATION OF A STATE WATER POLLUTION CONTROL REVOLVING FUND, AND RELATING TO THE ADMINISTRATION THEREOF.

\section{Bill Summary}

(Note: This summary applies to this bill as introduced and does not necessarily reflect any amendments which may be subsequently adopted.)

Declares that the construction, rehabilitation, operation, and maintenance of modern and efficient wastewater treatment facilities and other pollution control projects are essential to protecting and improving the water resources of the state. States that the federal "Water Quality Act of $1987^{\prime \prime}$ requires increased state and local participation in the financing of such projects. Specifies that the division of local government in the department of local affairs, the division of administration in the department of health, and the Colorado water resources and power development authority have the combined expertise necessary to allow the state to effectively and efficiently serve the wastewater treatment needs of the state.

Creates the water pollution control revolving fund in the authorlty for purposes of participating in such act. Authorizes the authority to issue bonds for the purpose of providing state matching funds for the federal program. Requires the water quality control commission to develop a project eligibility list for wastewater treatment systems and 
other projects authorized under such act. States that the project eligibility list shall be approved by joint resolution signed by the governor. Provides that no project may be financed unless it has been approved in such a joint resolution. Specifles that the authority has the sole discretion in proceeding with the financing of any project on the eligibility list. States that before any loan to a governmental agency may be made the project must be approved by the division of administration in the department of health pursuant to applicable provisions of the "Colorado Water Quality Control Act" and the financial loan package must be approved by the division of local government in the department of local affairs.

1 Be it enacted by the General Assembly of the State of Colorado: SECTION 1. Legislative declaration.

(1) The general

3 assembly hereby declares that the construction,

4 rehabilitation, operation, and maintenance of modern and

5 efficient wastewater treatment facilities and other water

6 pollution control projects are essential to protecting and

7 improving the water resources of the state. The United

8 States, pursuant to the federal "Water Quality Act of 1987",

9 requires increased state and local participation in the

10 financing of the cost of wastewater treatment projects. Said

11 water quality act requires each state to establish a water

12 pollution control revolving fund to be administered by an

13 instrumentality of the state before the state may receive

14 capitalization grants for such projects.

15 (2) The Colorado water resources and power development

16 authority was created to initiate, acquire, construct,

17 maintain, repair, and operate or cause to be operated water

18 management projects which include wastewater treatment

19 facilities and to issue its bonds to pay the cost of such 
1 projects. The division of local government in the department

2 of local affairs has the responsibility of assisting units of 3 local government in obtalning the benefits of various state 4 and federal programs. The division of administration in the 5 department of health has the responsibility of administering 6 the "Colorado Water Quality Control Act". The general 7 assembly hereby recognizes that the expertise of each of these 8 governmental agencies is necessary to allow the state to 9 participate in the federal "Water Quality Act of 1987". It is 10 the intent of the general assembly that these governmental 11 agencies cooperate in a manner which will efficiently and 12 effectively serve the wastewater treatment needs of the state. 13 (3) The creation of a water pollution control revolving 14 fund to be administered by the authority will enable the state 15 to comply with the provisions of said federal "Water Quality 16 Act of 1987", and the administration of said fund by said 17 authority is consistent with, and in furtherance of, the 18 powers and duties of the authority.

(4) The general assembly finds and declares that the 20 creation of a water pollution control revolving fund to be 21 administered by the Colorado water resources and power 22 development authority and the powers and duties conferred on 23 said authority pursuant to this act and the expenditure of 24 public moneys pursuant thereto constitute a valid public 25 purpose and are in the best interests of the state.

26 SECTION 2. 37-95-103, Colorado Revised Statutes, as 27 amended, is amended BY THE ADDITION OF A NEW SUBSECTION to 
1 read:

2 37-95-103. Definitions. (4.5) "Clean water act" means

3 the "Federal Water Pollution Control Act Amendments of 1972",

4 P.L. 92-500, and any act amendatory or supplemental thereto as

5 of the effective date of this section.

6 SECTION 3. Article 95 of title 37, Colorado Revised

7 Statutes, as amended, is amended BY THE ADDITION OF A NEW

8 SECTION to read:

9 37-95-107.6. Creation and administration of water

10 pollution control revolving fund. (1) There is hereby

11 created in the authority the water pollution control revolving

12 fund which shall be maintained and administered by the

13 authority and be available in perpetuity for the purposes

14 stated in this section. The authority is authorized to

15 establish such procedures as may be required to administer the

16 water pollution control revolving fund in accordance with the

17 clean water act and state law. The authority may create

18 separate accounts in the water pollution control revolving

19 fund which accounts may be pledged and assigned as security

20 for the payment of the bonds of the authority.

21 (2) (a) Subject to the provisions of the clean water act

22 and agreements with the holders of bonds of the authority, the

23 authority shall deposit in the water pollution control

24 revolving fund grants from the federal government or its

25 agencies allocated to the state for deposit in said fund;

26 state matching funds where required; loan principal, interest

27 and penalty payments; and other moneys determined by the 
1 authority to be deposited therein.

2 (b) Moneys in the water pollution control revolving fund 3 shall be expended in a manner consistent with terms and 4 conditions of the clean water act and may be used to provide 5 assistance to governmental agencies for the construction of 6 publicly owned wastewater treatment plants that appear on the 7 priority list under section 216 of the clean water act and as 8 are defined in section 212 of the clean water act; for 9 implementation of a nonpoint source pollution management 10 program under section 319 of the clean water act; and for any 11 other purposes permitted by the clean water act.

12 (c) Moneys on deposit in the water pollution control 13 revolving fund may be used by the authority for wastewater 14 treatment facilities through the making of loans to 15 governmental agencies; purchasing or refinancing debt 16 obligations of governmental agencies where the debt 17 obligations were incurred after March 7, 1985; purchasing 18 insurance for debt obligations of governmental agencies; 19 securing or providing revenues for payment of the principal 20 and interest on bonds of the authority; providing for the 21 costs of administering the water pollution control revolving 22 fund; and providing for any other expenditure consistent with 23 the clean water act and state law. Money not currently needed 24 for the operation of the water pollution control revolving 25 fund may be invested and all interest earned on such 26 investments shall be credited to the specific account, if any, 27 in the water pollution control revolving fund. 
1 (3) (a) The authority may make and contract to make

2 loans to governmental agencies in accordance with and subject

3 to the provisions of this section to finance the cost of

4 wastewater treatment system projects which are on the project

5 elfgibility list established pursuant to subsection (4) of

6 this section and any other projects authorized under the clean

7 water act and which the governmental agencies may lawfully

8 undertake or acquire under state law, including, but not

9 limited to, applicable provisions of the "Colorado Water

10 Quality Control Act", article 8 of title 25, C.R.S., and for

11 which the governmental agencies are authorized by law to

12 borrow money. The loans may be made subject to such terms and

13 conditions as the authority shall determine to be consistent

14 with the purposes thereof. Each loan by the authority and the

15 terms and conditions thereof shall be subject to approval by

16 the division of local government of the department of local

17 affairs. The division of local government in the department

18 of local affairs may establish procedures with respect to

19 providing financial assistance from the water pollution

20 control revolving fund. Each loan to a local governmental

21 agency shall be evidenced by notes, bonds, or other

22 obligations thereof issued to the authority. In the case of

23 each governmental agency, notes and bonds to be issued to the

24 authority by the local government agency shall be authorized

25 and issued as provided by law for the issuance of notes and

26 bonds by the governmental agency, may be sold at private sale

27 to the authority at any price, whether or not less than par 
1 value, and shall be subject to redemption prior to maturity at

2 such times and at such prices as the authority and

3 governmental agency may agree. Each loan to a local

4 government agency and the notes, bonds, or other obligations

5 thereby issued shall bear interest at such rate or rates per

6 annum at or below market interest rate and shall be for such

7 terms not to exceed twenty years as the authority and the

8 governmental agency may agree.

9 (b) The authority is authorized, from moneys in the 10 water pollution control revolving fund, to purchase or 11 refinance or purchase insurance for the payment of all or any 12 portion of the principal and interest on bonds, notes, or 13 other obligations issued by a governmental agency to finance 14 the cost of any wastewater treatment system project which the 15 governmental agency may lawfully undertake or acquire under 16 state law, including, but not limited to, applicable 17 provisions of the "Colorado Water Quality Control Act", 18 article 8 of title 25 , C.R.S., and for which the governmental 19 agency is authorized by law to borrow money. Each purchase or 20 refinancing or purchase of insurance by the authority or any 21 other application of moneys on deposit in the water pollution 22 control revolving fund and the terms and conditions thereof 23 shall be subject to approval by the division of local 24 government in the department of local affairs.

25 (c) The authority may charge to and collect from 26 governmental agencies, fees and charges in connection with the 27 authority's loans or other services, including, but not 
1 I imited to, fees and charges sufficient to reimburse the

2 authority for all reasonable costs necessarlly incurred by it

3 in connection with its financing and the establishment and

4 maintenance of reserves or other funds, as the authority may

5 determine to be reasonable.

6 (4) (a) The water quality control commission shall

7 develop a project eligibllity list for wastewater treatment

8 systems and other projects authorized under the clean water

9 act. The project eligibility list shall be in conformance

10 with applicable provisions of the clean water act and state

11 law. On or before April 1, 1988, the project eligtbility list

12 shall be approved by joint resolution signed by the governor.

13 (b) Additions or modifications to the project

14 eligibility list which have been developed by the water

15 quality control commission shall be submitted to the general

16 assembly on or before January 15 of each year. On or before

17 April 1 of each year, such additions or modifications shall be

18 approved by a joint resolution signed by the governor.

19 (c) No funds may be expended from the water pollution

20 control revolving fund or bonds issued by the authority

21 pursuant to subsection (6) of this section for any wastewater

22 treatment system project unless the wastewater treatment

23 system project is on the project eligibility list approved by

24 the general assembly. Financial assistance for a project

25 pursuant to this section may be provided regardless of the

26 rank of such project on the eligibility list.

27 (5) The division of local government in the department 
1 of local affairs, the division of administration in the

2 department of health, and the authority shall develop an

3 intended use plan in compliance with the clean water act. The

4 intended use plan shall include, in addition to the material

5 required by, but not be limited to, the clean water act, an

6 enumeration of the bonds the authority would need to issue,

7 including the amounts thereof and the terms and conditions

8 therefor, a list of loans to be made to governmental agencies,

9 including the terms and conditions thereof and the anticipated

10 rate of interest per annum and repayment schedule therefor. A

11 decision to proceed with the issuance of such bonds shall be

12 entirely within the discretion of the authority.

13 (6) In order to finance the cost of making loans to 14 governmental agencies and provide reserves therefor pursuant 15 to paragraph (a) of subsection (3) of this section, the 16 authority is authorized to issue bonds pursuant to the 17 provisions of this article.

18 (7) The authority, on behalf of the state, with the 19 written approval of the department of health, is authorized to 20 enter into such agreements with the United States as may be 21 necessary to comply with the provisions of the federal "Water 22 Quality Act of 1987" (P.L. 100-4) and as otherwise may be 23 required to provide for the capitalization of the water 24 pollution control revolving fund from federal grant moneys.

25 (8) The provisions of sections 37-95-107 and 37-95-107.5 26 shall not be applicable to any wastewater treatment system 27 project on the project eligibility list approved by the 
1 general assembly pursuant to subsection (4) of this section.

2 SECTION 4. Safety clause. The general assembly hereby

3 finds, determines, and declares that this act is necessary

4 for the immediate preservation of the public peace, health,

5 and safety. 


\section{BILL 3}

\section{A BILL FOR AN ACT}

1 CONCERNING AMENDMENTS TO THE "COLORADO WATER QUALITY CONTROL ACT".

\section{Bill Summary}

(Note: This summary applies to this bill as introduced and does not necessarily reflect any amendments which may be subsequent ly adopted.)

Decreases the number of days' notice which must be given for a hearing to promulgate any water quality standard or any control regulation. Limits the period of time within which a person who is suspected of violating any permit or control regulation may request a sample of water or water pollutants. Decreases the length of time for public comment on a permit application. Clarifies that the division of administration of the department of health may grant a variance only to the extent authorized by the federal act or implementing regulations. Authorizes criminal penalties for pretreatment violations.

Be it enacted by the General Assembly of the State of Colorado:

5 Revised Statutes, 1982 Repl. Vol., are amended to read:

25-8-105. Regional wastewater management plans -

7 amendments.

(a) Regional wastewatef WATER QUALITY 
1 federal act as "208 plans" may be developed by designated

2 planning agencies or by the state for nondesignated areas or

3 for statewide purposes.

4 (2) Each regional wastewater WATER QUALITY management

5 plan and each amendment to such a plan must be either

6 developed or reviewed by the division.

7 (3) (a) The commission, after notice and hearing, shall

8 approve, conditionally approve, or reject proposed regional

9 wastewater WATER QUALITY management plans and amendments

10 thereto. The commission shall approve, conditionally approve,

11 or reject a plan or an amendment developed by a management or

12 planning agency within one hundred eighty days after submittal

13 of the plan or amendment by the management or planning agency

14 to the division. Only those portions of a regional wastewater

15 WATER QUALITY management plan which are adopted as a

16 regulation by the commission pursuant to section 24-4-103,

17 C.R.S., 1973, shall be binding on regulatory decisions,

18 including, but not limited to, site approvals, construction

19 grants, or point or nonpoint source control decisions. Only

20 those plans or portions thereof which are adopted by the

21 commission as regulations shall be binding for purposes of any

22 federal law, regulation, or action.

23 (b) Notwithstanding the provisions of paragraph (a) of

24 this subsection (3), the commission may delegate to the

25 division the authority to approve, conditionally approve, or

26 reject nonrule-making amendments to regional wastewatef WATER

27 QUALITY management plans. If the commission delegates such 
1 authority, the division shall give notice of its decision on

2 an amendment to the commission and to anyone who has requested 3 notice of amendments to the affected plan. Notice of such 4 decision shall also be included on the next commission agenda. 5 Upon a request by any affected person, the commission shall 6 review the division's decision. The decision of the division 7 shall be final within forty-five days after agenda notice of 8 the decision has been given unless review is requested by an 9 affected person.

10 (4) The governor may certify to the federal 11 environmental protection agency a regional wastewatef WATER 12 QUALITY management plan or an amendment thereto which has been 13 approved by the commission or an amendment thereto which has 14 become final after approval by the division. The governor may 15 designate planning agencies for the purposes of the federal 16 act.

17 SECTION 2. 25-8-402 (1), Colorado Revised Statutes, 1982

18 Repl. Vol., is amended to read:

19 25-8-402. Procedures to be followed in classifying state 20 waters, and setting standards and control regulations.

21 (1) Prior to the classification of state waters, and 22 promulgating any water quality standard or any control 23 regulation authorized in this article, the commission shall 24 conduct a public hearing thereon as provided in section 25 24-4-103, C.R.S. 1973, Notice of any such hearing shall 26 conform to the requirements of section 24-4-103, C.R.S., 1973, 27 but such notice shall be given at least sixty FORTY-FIVE days 
1 prior to the hearing and shall include each proposed standard 2 or regulation.

3 SECTION 3. 25-8-405 (1), Colorado Revised Statutes, 1982

4 Repl. Vol., is amended to read:

5 25-8-405. Samples, secret processes. (1) If samples of 6 water or water pollutants are taken for analysis and a 7 violation of any permit or control regulation is suspected, a 8 representative portion of the sample shall be furnished upon 9 request, WITHIN SIX MONTHS AFTER COLLECTION, to the person who 10 is believed to be responsible for such suspected violation. A 11 representative portion of such sample shall be furnished UPON 12 REQUEST, WITHIN SIX MONTHS AFTER COLLECTION, to any suspected

13 violator whenever any remedial action is taken with respect 14 thereto by the division. A duplicate of every analytical 15 report pertaining to such sample shall also be furnished as 16 soon as practicable to such person.

17 SECTION 4. 25-8-502 (3) (c), Colorado Revised Statutes,

181982 Repl. Vol., is amended to read:

19 25-8-502. Application - definitions - fees - water 20 quality control fund - public participation. (3) (c) The 21 period for public comment shall close fefty-five THIRTY days 22 from the date of notice of the permit application and the 23 division's preliminary analysis thereof; except that, if a 24 public meeting is held on the application and analysis, the 25 period for public comment shall close sixty days from the date 26 of notice of the application. and-anatysis.

27 SECTION 5. 25-8-503 (2) and (9). Colorado Revised 
1 Statutes, 1982 Repl. Vol., as amended, are amended to read: 25-8-503. Permits - when required and when prohibited -

3 variances. (2) No permit shall be issued which is 4 inconsistent with any duly promulgated and controlling state, 5 regional, or local land use plan or any portion of an approved 6 regional wastewatef WATER QUALITY management plan which has 7 been adopted as a regulation pursuant to this article, unless 8 all other requirements and conditions of this act have been 9 met or will be met pursuant to a schedule of compliance or a 10 variance specifying treatment requirements as determined by 11 the division.

(9) The division may grant a variance from otherwise applicable requirements ONLY to the extent authorized in the federal act or implementing regulations. Variances may be granted for no longer than the duration of the permit. Variances shall be granted or renewed according to the procedure established in section 25-8-401 (5). Any variances granted prior to June 4, 1985, which were validly granted under the provisions then in effect shall be valid according to their original terms.

SECTION 6. 25-8-609 (1), Colorado Revised Statutes, 1982 Repl. Vol., as amended, is amended BY THE ADDITION OF A NEW PARAGRAPH to read:

25-8-609. Criminal pollution of state waters -
penalties. (1) (e) In violation of any pretreatment regulations promulgated by the commission. SECTION 7. 25-8-702 (1), Colorado Revised Statutes, 1982 
1 Rep 1. Vol., is REPEALED AND REENACTED, WITH AMENDMENTS, to

2 read:

3

25-8-702. Approval for commencement of construction.

4 (1) No person shall commence the construction of any domestic

5 wastewater treatment works or the enlargement of the capacity

6 of an existing domestic wastewater treatment works, unless the

7 site location and the design for the construction or expansion

8 have been approved by the division.

9 SECTION 8. Effective date. This act shall take effect

10 July 1, 1988.

11 SECTION 9. Safety clause. The general assembly hereby 12 finds, determines, and declares that this act is necessary 13 for the immediate preservation of the public peace, health, 14 and safety. 


\section{BILL 4}

A BILL FOR AN ACT

1 CONCERNING WATER QUALITY CONTROL PERMITS SYSTEM FEES.

\section{Bi11 Summary}

(Note: This summary applies to this bill as introduced and does not necessarily reflect any amendments which may be subsequent iy adopted.l permits.

Extends the expiration of the annual fee for discharge

2 Be it enacted by the General Assembly of the State of Colorado:

SECTION 1. 25-8-502

(b) (I), Colorado Revised

4 Statutes, 1982 Rep 1. Vol., as amended, is amended to read:

5 25-8-502. Application - definitions - fees - water

6 quality control fund - public participation. (1) (b) (I) The

7 only fee the division may assess is an annual fee upon a 8 discharger, and such fee shall be in accordance with the 9 following schedule: 


\begin{tabular}{|c|c|c|c|c|c|}
\hline 1 & & \multicolumn{2}{|c|}{ Facility Categories and Subcategories } & \multicolumn{2}{|c|}{ Fiscal Years } \\
\hline 2 & & & & 1983 & $3-84$ \\
\hline 3 & & & or Permit Fees & through & $\underline{1987-88}$ \\
\hline 4 & & & & $\underline{1992}$ & -93 \\
\hline 5 & & & & Annua 1 & Fees \\
\hline 6 & (A) & Category 01 & Sand and gravel and placer & & \\
\hline 7 & & & $\underline{\text { minting }}$ & & \\
\hline 8 & & Subcategory 1 & Pit dewatering only & $\$$ & 220 \\
\hline 9 & & Subcategory 2 & Pit dewatering and/or & & \\
\hline 10 & & & washwater discharge & $\$$ & 250 \\
\hline 11 & & Subcategory 3 & Mercury use with discharge & & \\
\hline 12 & & & Impact & $\$$ & 280 \\
\hline 13 & (B) & Category 02 & Coal mining & & \\
\hline 14 & & Subcategory 1 & Sedimentation ponds, surface & & \\
\hline 15 & & & runoff only & $\$$ & 430 \\
\hline 16 & & Subcategory 2 & Mine water, preparation & & \\
\hline 17 & & & plant discharge & $\$$ & 580 \\
\hline 18 & (C) & Category 03 & Hardrock mining & & \\
\hline 19 & & Subcategory 1 & Mine dewatering from 0 up to & & \\
\hline 20 & & & 49,999 gallons per day & $\$$ & 500 \\
\hline 21 & & Subcategory 2 & Mine dewatering from 50,000 & & \\
\hline 22 & & & up to 999,999 gallons per & & \\
\hline 23 & & & day & $\$$ & 940 \\
\hline 24 & & Subcategory 3 & dewatering & & \\
\hline 25 & & & $1,000,000$ gallons per day & & \\
\hline 26 & & & or over & &, 440 \\
\hline 27 & & Subcategory 4 & Mine dewatering and milling & & \\
\hline
\end{tabular}




\begin{tabular}{|c|c|c|c|c|}
\hline 1 & & with no discharge & & 1,440 \\
\hline 2 & Subcategory 5 & Mine dewatering and milling & & \\
\hline 3 & & with discharge & & 4,330 \\
\hline 4 & Subcategory 6 & No discharge & $\$$ & 500 \\
\hline 5 & (D) Category 04 & Oil shale & & \\
\hline 6 & Subcategory 1 & Sedimentation ponds, surface & & \\
\hline 7 & & runoff only & $\$$ & 870 \\
\hline 8 & Subcategory 2 & Mine water from 0 up to & & \\
\hline 9 & & 49,999 gallons per day & $\$$ & 940 \\
\hline 10 & Subcategory 3 & Mine water from 50,000 up to & & \\
\hline 11 & & 999,999 gallons per day & & 1,170 \\
\hline 12 & Subcategory 4 & Mine water from $1,000,000$ & & \\
\hline 13 & & gallons per day or over & $\$$ & 1,440 \\
\hline 4 & Subcategory 5 & Mine water and process water & & \\
\hline 15 & & discharge & $\$$ & 4,330 \\
\hline 16 & Subcategory 6 & No discharge & $\$$ & 800 \\
\hline 17 & (E) Category 05 & Agricultural facilities & & \\
\hline 18 & Subcategory 1 & Under 5,000 maximum animal & & \\
\hline 19 & & units & $\$$ & 80 \\
\hline 20 & Subcategory 2 & 5,000 and over maximum & & \\
\hline 21 & & animal units & $\$$ & 110 \\
\hline 22 & (F) Category 06 & Water treatment plants & & \\
\hline 23 & Subcategory 1 & Intermittent discharge & $\$$ & 250 \\
\hline 24 & Subcategory 2 & Rout ine discharge & $\$$ & 360 \\
\hline 25 & (G) Category 07 & General permits & & \\
\hline 26 & Subcategory 1 & Sand and gravel & $\$$ & 220 \\
\hline 27 & Subcategory 2 & Construction dewatering (not & & \\
\hline
\end{tabular}


Subcategory 3 Hydrostatic pipeline testing

4 (H) Category 08 Power plants

Subcategory 1 cooling water only, no discharge

$\$ 500$

Subcategory 2 Process water from 0 up to

$\$ 940$

Subcategory 3 Process water from 50,000 up to 999,999 gallons per day

$\$ 1,440$

Subcategory 4 Process water from $1,000,000$

$$
\text { up to } 4,999,999 \text { gallons }
$$

$$
\text { per day }
$$

$\$ 4,330$

Subcategory 5 Process water from 5,000,000

$$
\text { gallons per day or over }
$$
(I) Category 09 Sugar processing Subcategory 1 Cooling water only, no

$$
\text { discharge }
$$

Subcategory 2 Process water from 0 up to

$$
\text { 49,999 gallons per day }
$$

Subcategory 3 Process water from 50,000 up

$$
\text { to } 999,999 \text { gallons per day } \$ 1,620
$$

Subcategory 4 Process water from $1,000,000$

$$
\begin{aligned}
& \text { up to } 4,999,999 \text { gallons } \\
& \text { per day }
\end{aligned}
$$

Subcategory 5 Process water from 5,000,000

$$
\text { gallons per day or over } \$ 4,330
$$




\begin{tabular}{|c|c|c|c|}
\hline 1 & (J) Category 10 & Petroleum refining & \\
\hline 2 & Subcategory 1 & Cooling water only, no & \\
\hline 3 & & discharge & 500 \\
\hline 4 & Subcategory 2 & Process water from 0 up to & \\
\hline 5 & & 49,999 gallons per day & $\$ 1,120$ \\
\hline 6 & Subcategory 3 & Process water from 50,000 up & \\
\hline 7 & & to 999,999 gallons per day & $\$ 1,440$ \\
\hline 8 & Subcategory 4 & Process water from $1,000,000$ & \\
\hline 9 & & up to $4,999,999$ gallons & \\
\hline 10 & & per day & $\$ 4,330$ \\
\hline 11 & Subcategory 5 & Process water from $5,000,000$ & \\
\hline 12 & & gallons per day or over & $\$ 4,330$ \\
\hline 13 & (K) Category 11 & Fish hatcheries & \\
\hline 14 & No subcategories at & th this time & 360 \\
\hline 15 & (L) Category 12 & Manufacturing and other & \\
\hline 16 & & industry & \\
\hline 17 & Subcategory 1 & Cooling water only & 500 \\
\hline 18 & Subcategory 2 & Process water from 0 up to & \\
\hline 19 & & 49,999 gallons per day & 940 \\
\hline 20 & Subcategory 3 & Process water from 50,000 up & \\
\hline 21 & & to 999,999 gallons per day & $\$ 1,440$ \\
\hline 22 & Subcategory 4 & Process water from $1,000,000$ & \\
\hline 23 & & up to $4,999,999$ gallons & \\
\hline 24 & & per day & $\$ 4,330$ \\
\hline 25 & Subcategory 5 & Process water from $5,000,000$ & \\
\hline 26 & & up to $19,999,999$ gallons & \\
\hline 27 & & per day & $\$ 5,320$ \\
\hline
\end{tabular}




\begin{tabular}{|c|c|c|c|c|c|}
\hline 1 & & Subcategory 6 & Process water $20,000,000$ & & \\
\hline 2 & & & gallons per day or over & & 3,660 \\
\hline 3 & & Subcategory 7 & No discharge & $\$$ & 650 \\
\hline 4 & (M) & Category 20 & wastewater & & \\
\hline 5 & & & lagoons & & \\
\hline 6 & & Subcategory 1 & Sewage from 0 up to 49,999 & & \\
\hline 7 & & & gallons per day & $\$$ & 230 \\
\hline 8 & & Subcategory 2 & Sewage from 50,000 up to & & \\
\hline 9 & & & 99,999 gallons per day & $\$$ & 370 \\
\hline 10 & & Subcategory 3 & Sewage from 100,000 up to & & \\
\hline 11 & & & 499,999 gallons per day & $\$$ & 540 \\
\hline 12 & & Subcategory 4 & Sewage from 500,000 up to & & \\
\hline 13 & & & 999,999 gallons per day & $\$$ & 930 \\
\hline 14 & & Subcategory 5 & Sewage from $1,000,000$ up to & & \\
\hline 15 & & & $1,999,999$ gallons per day & $\$$ &, 390 \\
\hline 16 & & Subcategory 6 & Sewage $2,000,000$ gallons per & & \\
\hline 17 & & & day or over & $\$$ & .830 \\
\hline 18 & $(N)$ & Category 21 & Domestic wastewater & & \\
\hline 19 & & & mechanical plants & & \\
\hline 20 & & Subcategory 1 & Sewage from 0 up to 19,999 & & \\
\hline 21 & & & gallons per day & $\$$ & 270 \\
\hline 22 & & Subcategory 2 & Sewage from 20,000 up to & & \\
\hline 23 & & & 49,999 gallons per day & $\$$ & 430 \\
\hline 24 & & Subcategory 3 & Sewage from 50,000 up to & & \\
\hline 25 & & & 99,999 gallons per day & $\$$ & 630 \\
\hline 26 & & Subcategory 4 & Sewage from 100,000 up to & & \\
\hline 27 & & & 499,999 gallons per day & $\$$ & 980 \\
\hline
\end{tabular}




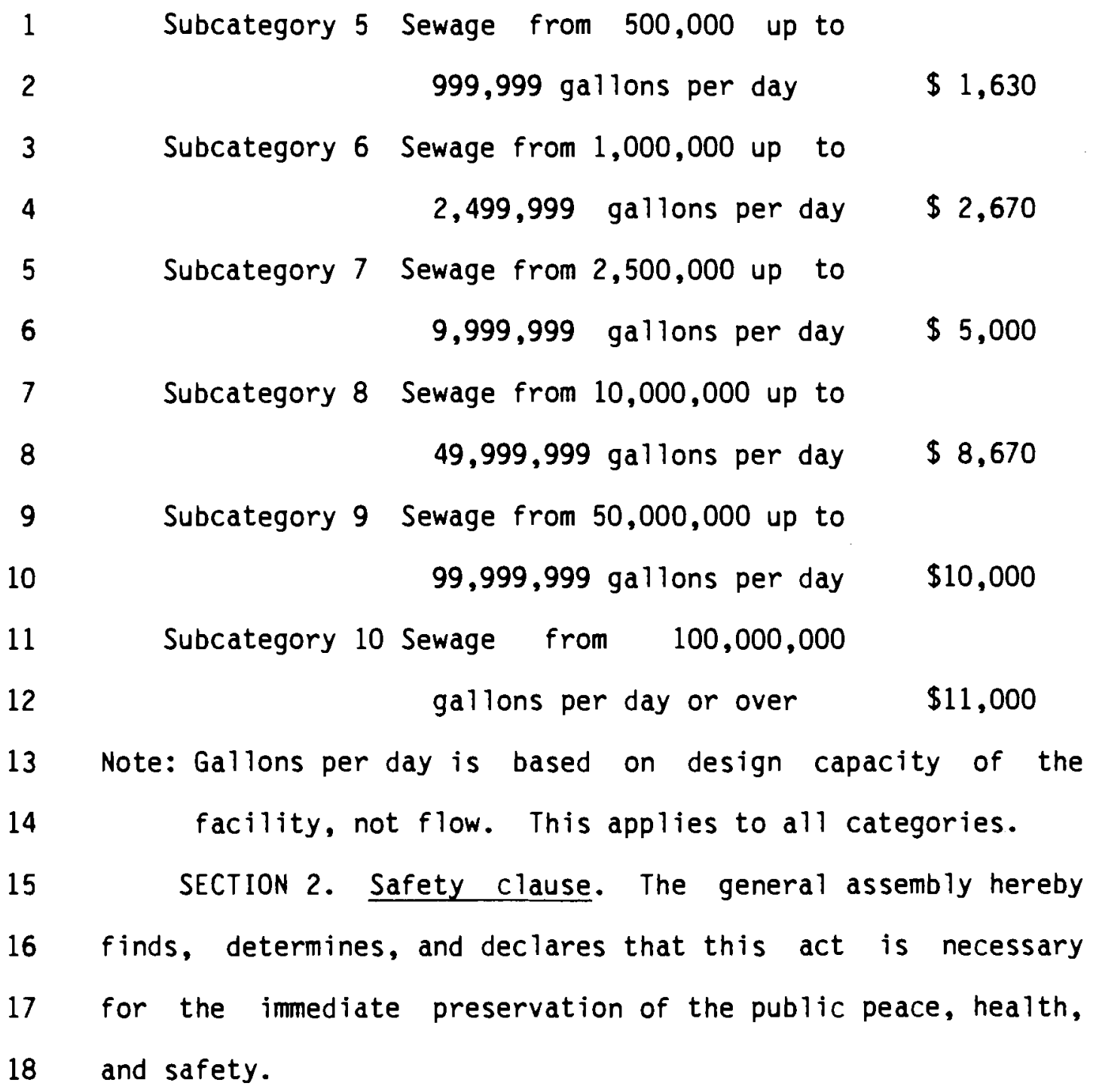


BILL 5

A BILL FOR AN ACT

1 CONCERNING THE CREATION OF THE CHERRY CREEK BASIN WATER 2 QUALITY AUTHORITY.

\section{Bill Summary}

(Note: This summary applies to this bill as introduced and does not necessarily reflect any amendments which may be subsequentiy adopted.)

Creates the Cherry Creek basin water quality authority for the purpose of maintaining the water quality in Cherry Creek reservoir. Enumerates powers and duties of the authority, including the power to issue bonds and to levy special assessments. Defines the boundaries of the authority.

3 Be it enacted by the General Assembly of the State of Colorado: SECTION 1. Title 25, Colorado Revised Statutes, 1982 5 Repl. Vol., as amended, is amended BY THE ADDITION OF A NEW 6 ARTICLE to read:

ARTICLE 8.5 Cherry Creek Basin Water Quality Authority assembly hereby finds and declares that the organization of a

11 Cherry Creek basin water quality authority will: 
(a) Be for the public benefit and advantage of the

2 people of the state of Colorado;

3 (b) Benefit the inhabitants and landowners within the 4 authority by preserving water quality in Cherry Creek and 5 Cherry Creek reservoir;

6 (c) Benefit the people of the state of Colorado by 7 preserving waters for recreation, fisheries, water supplies, 8 and other beneficial uses;

(d) Promote the health, safety, and welfare of the 10 people of the state of Colorado.

11 (2) It is further declared that the authority will 12 provide for effective efforts by the various counties, 13 municipalities, special districts, and landowners within the 14 boundaries of the authorjty in the protection of water 15 quality.

16 (3) It is further declared that the authority should 17 provide that new developments and construction activities pay 18 their equitable proportion of costs for water quality 19 preservation and facilities.

20 (4) This article, being necessary to secure the public 21 health, safety, convenience, and welfare, shall be liberally 22 construed to effect its purposes.

23 25-8.5-102. Definitions. As used in this article, 24 unless the context otherwise requires:

25 (1) "Authority" means the Cherry Creek basin water 26 quality authority created pursuant to section 25-8.5-103.

(2) "Board" means the governing body of the authority 
1 provided for in section 25-8.5-106.

(3) "County" means any county enumerated in article 5 of

3 title 30 , C.R.S.

4

5

6

(4) "Municipality" means a municipality as defined in section 31-1-101 (6), C.R.S.

(5) "Publication" means three consecutive weekly advertisements in a newspaper or newspapers of general circulation within the boundaries of the authority. It shall not be necessary that an advertisement be made on the same day of the week in each of the three weeks, but not less than twelve days, excluding the day of first publication, shall intervene between the first publication and the last publication. Publication shall be complete on the date of the last publication.

(6) "Resolution" means an ordinance as passed by a member municipality or a resolution as passed by a member county or special district.

(7) "Special district" means any district created pursuant to article 1 of title 32, C.R.S., which has the power to provide sanitation services or water and sanitation services and has wastewater treatment facilities within the boundaries of the authority.

(8) "Wastewater treatment facility" means a facility providing wastewater treatment services which has a designed capacity to receive sewage for treating, neutralizing, 26 stabilizing, and reducing pollutants contained therein prior 27 to the disposal or discharge of the treated sewage. 
1 "Wastewater treatment facility" does not include any

2 pretreatment facilities, lift stations, interceptor lines, or

3 other transmission facilities to transmit sewage effluent

4 outside the boundaries of the authority.

5 25-8.5-103. Creation and organization. The Cherry Creek

6 basin water quality authority is hereby created. The

7 authority shall be a quasi-municipal corporation and political

8 subdivision of the state, with the powers provided in this

9 article.

10 25-8.5-104. Boundaries of the authority. (1) The

11 boundaries of the authority shall be determined by the

12 authority, subject to the following:

13 (a) The boundaries shall be limited to the drainage

14 basin of Cherry Creek from its headwaters to the dam at Cherry

15 Creek reservoir, which the general assembly hereby finds to

16 be:

17 (I) Arapahoe county: Portions of sections thirty-five 18 and thirty-six, township four south, range sixty-seven west of 19 the sixth principal meridian; a portion of section thirty-one, 20 township four south, range sixty-six west of the sixth 21 principal meridian; portions of sections one, two, three, ten, 22 fifteen, twenty-two, twenty-three, twenty-seven, and 23 thirty-four, and all of sections eleven, twelve, thirteen, 24 fourteen, twenty-four, twenty-five, twenty-six, thirty-five 25 and thirty-six, township five south, range sixty-seven west of 26 the sixth principal meridian; all of sections seven, 27 seventeen, eighteen, nineteen, twenty, twenty-one, twenty-two, 
1 twenty-five, twenty-six, twenty-seven, twenty-eight,

2 twenty-nine, thirty, thirty-one, thirty-two, thirty-three,

3 thirty-four, thirty-five, thirty-six and portions of sections

4 five, six, eight, nine, fourteen, fifteen, sixteen,

5 twenty-three and twenty-four, township five south, range

6 sixty-six west of the sixth principal meridian; all of section

7 thirty-one and portions of sections nineteen, twenty-nine,

8 thirty, and thirty-two, township five south, range sixty-five

9 west of the sixth principal meridian;

10 (II) Douglas county: Portions of sections four, nine,

11 sixteen, twenty-one, twenty-eight and thirty-three, and all of

12 sections five, six, seven, eight, seventeen, eighteen,

13 nineteen, twenty, twenty-nine, thirty, thirty-one, and

14 thirty-two, township six south, range sixty-five west of the

15 sixth principal meridian; township six south, range sixty-six

16 west of the sixth principal meridian; portions of sections

17 three, ten, fifteen, twenty-one, twenty-two, twenty-eight,

18 thirty-one, thirty-two and thirty-three, and all of sections

19 one, two, eleven, twelve, thirteen, fourteen, twenty-three,

20 twenty-four, twenty-five, twenty-six, twenty-seven,

21 thirty-four, thirty-five and thirty-six, township six south,

22 range sixty-seven west of the sixth principal meridian;

23 portions of sections four, nine, sixteen, and twenty-one, and

24 all of sections five, six, seven, eight, seventeen, eighteen,

25 nineteen, twenty, twenty-eight, twenty-nine, thirty,

26 thirty-one, thirty-two, and thirty-three, township seven

27 south, range sixty-five west of the sixth principal meridian; 
1 township seven south, range sixty-six west of the sixth

2 principal meridian; portions of sections four, five, nine,

3 fourteen, fifteen, sixteen, twenty-three, twenty-five,

4 twenty-six, and thirty-six, and all of sections one, two,

5 three, ten, eleven, twelve, thirteen, and twenty-four,

6 township seven south, range sixty-seven west of the sixth

7 principal meridian; portions of sections twenty-eight and

8 thirty-three and all of sections four, five, six, seven,

9 eight, nine, sixteen, seventeen, eighteen, nineteen, twenty,

10 twenty-one, twenty-nine, thirty, thirty-one, and thirty-two,

11 township eight south, range sixty-five west of the sixth

12 principal meridian; portions of sections six, seven, eighteen,

13 nineteen, twenty-nine, thirty, and thirty-one, and all of

14 sections one, two, three, four, five, eight, nine, ten,

15 eleven, twelve, thirteen, fourteen, fifteen, sixteen,

16 seventeen, twenty, twenty-one, twenty-two, twenty-three,

17 twenty-four, twenty-five, twenty-six, twenty-seven,

18 twenty-eight, thirty-two, thirty-three, thirty-four,

19 thirty-five and thirty-six, township eight south, range

20 sixty-six west of the sixth principal meridian; a portion of

21 section one, township eight south, range sixty-seven west of

22 the sixth principal meridian; all of sections four, five, six,

23 seven, eight, nine, sixteen, seventeen, eighteen, nineteen,

24 twenty, twenty-one, twenty-eight, twenty-nine, thirty,

25 thirty-one, thirty-two and thirty-three, township nine south,

26 range sixty-five west of the sixth principal meridian; all of

27 township nine south, range sixty-six west excepting portions 
1 of sections six and seven; portions of sections thirteen,

2 twenty-three, twenty-four, twenty-five, and thirty-six, 3 township nine south, range sixty-seven west of the sixth 4 principal meridian; portions of sections twenty-eight and 5 thirty-three, and all of sections four, five, six, seven, 6 eight, nine, sixteen, seventeen, eighteen, nineteen, twenty, 7 twenty-one, twenty-nine, thirty, thirty-one, and thirty-two, 8 township ten south, range sixty-five west of the sixth 9 principal meridian; portions of sections five, six, seven, 10 eight, seventeen, eighteen, nineteen, twenty-nine, thirty, 11 thirty-one, and all of sections one, two, three, four, nine, 12 ten, eleven, twelve, thirteen, fourteen, fifteen, sixteen, 13 twenty, twenty-one, twenty-two, twenty-three, twenty-four, 14 twenty-five, twenty-six, twenty-seven, twenty-eight, 15 thirty-two, thirty-three, thirty-four, thirty-five and 16 thirty-six, township ten south, range sixty-six west of the 17 sixth principal meridian; a portion of section one, township 18 ten south range sixty-seven west of the sixth principal 19 meridian;

(III) Elbert county: Portions of sections twenty-two, 21 twenty-seven, and thirty-four, township seven south, range 22 sixty-five west of the sixth principal meridian; portions of 23 sections three, ten, fifteen, twenty-two, twenty-seven and 24 thirty-four, township eight south, range sixty-five west of 25 the sixth principal meridian; portions of sections three, ten, 26 eleven, fourteen, twenty-two, twenty-seven and thirty-four and 27 all of section fifteen, township nine south, range sixty-five 
1 west of the sixth principal meridian; portions of sections

2 two, three, ten, eleven, fifteen, twenty-two, twenty-seven and

3 thirty-four, township ten south, range sixty-five west of the

4 sixth principal meridian;

5 (IV) El Paso county: Portions of sections three, ten, 6 eleven, fourteen, fifteen, twenty-two, twenty-seven, 7 twenty-eight, thirty-one, thirty-three and all of sections 8 four, five, six, seven, eight, nine, sixteen, seventeen, 9 eighteen, nineteen, twenty, twenty-one, twenty-nine, thirty, 10 and thirty-two, township eleven south, range sixty-five west 11 of the sixth principal meridian; portions of sections seven, 12 eight, seventeen, eighteen, twenty, twenty-one, twenty-two, 13 twenty-five, twenty-six, twenty-seven, thirty-six and all of 14 sections one, two, three, four, five, six, nine, ten, eleven, 15 twelve, thirteen, fourteen, fifteen, sixteen, twenty-three, 16 and twenty-four, township eleven south, range sixty-six west 17 of the sixth principal meridian; a portion of section one, 18 township eleven south, range sixty-seven west of the sixth 19 principal meridian; portions of sections four, five, and six, 20 township twelve south, range sixty-five west of the sixth 21 principal meridian;

22 (b) Lands within the boundaries identified in paragraph 23 (a) of this subsection (1) may be excluded from the authority 24 pursuant to section $25-8.5-117$.

(2) The authority shall maintain a current map, showing all lands that are included in the authority's boundaries. 25-8.5-105. Authority members. (1) The following 
1 governmental entities shall be members of the authority:

(a) Every county which has property within the

3 authority's boundaries;

4 (b) Every municipality which has property within the 5 authority's boundaries; and

6 (c) Every special district which includes in its service 7 area property within the Cherry Creek basin and which owns and 8 operates a wastewater treatment services facility in the 9 Cherry Creek basin. For the purposes of this paragraph (c), 10 wastewater treatment services shall mean a wastewater 11 treatment facility with a designed capacity to receive more 12 than two thousand gallons of sewage per day.

13 25-8.5-106. Board of directors. (1) The governing body 14 of the authority shall be a board of directors which shall 15 exercise and perform all powers, rights, privileges, and 16 duties invested or imposed by this article.

17 (2) Each authority member shall appoint one 18 representative and two alternates to serve on the board. Any 19 county, municipality, or special district that provides 20 wastewater treatment services by contract with another entity 21 which is a member of the authority shall not be entitled to a 22 separate member on the board.

(3) Directors shall be appointed for terms of two years. 24 Notice of each appointment shall be given to the recording 25 secretary for the authority.

(4) No director shall receive compensation as an 27 employee of the authority. Reimbursement of actual expenses 
1 for directors shall not be considered compensation.

(5) An appointment to fill a vacancy on the board shall 3 be made by the authority member for the remainder of the 4 unexpired term.

(6) If a board member or designated alternate fails to 6 attend two consecutive regular meetings of the board, the 7 authority may submit a written request to the appointing 8 authority member to have its representative attend the next 9 regular meeting. If, following such request, said 10 representative fails to attend the next regular board meeting, 11 the board may appoint an interim representative from the 12 authority member's jurisdiction to serve until the authority 13 member appoints a new representative.

14 (7) An authority member, at its discretion, may remove 15 from office any board member or designated alternate 16 representing the authority member and appoint a successor.

17 (8) The board shall elect one of its members as chairman 18 of the authority and one of its members as secretary-treasurer 19 and shall appoint a recording secretary who may be a member of 20 the board.

21 (9) The recording secretary shall keep, in a well-bound 22 book, a record of all of the authority's meetings, 23 resolutions, certificates, contracts, bonds given by employees 24 or contractors, and all corporate acts which shall be open to 25 inspection of all interested parties.

26 (10) The secretary-treasurer shall keep strict and 27 accurate accounts of all money received by and disbursed for 
1 and on behalf of the authority.

2 25-8.5-107. Voting. (1) Each authority member, through

3 its designated director or designated alternate acting in the

4 director's place, shall be entitled to one vote.

5 (2) Board action upon wasteload allocations, site

6 location, or site plans selected pursuant to section 25-8-702,

7 discharge permits secured pursuant to section 25-8-501,

8 amendments to the authority's wastewater management plan, and

9 all budget and funding decisions shall require a vote of the

10 following combinations of member votes:

11 (a) An affirmative vote of fifty percent of the counties

12 which are members of the authority; and

13 (b) An affirmative vote of a majority of the

14 municipalities which are members of the authority; and

15 (c) An affirmative vote of a majority of the special

16 districts which are members of the authority.

17 (3) All decisions of the board not enumerated in

18 subsection (2) of this section shall be made and decided by a

19 majority of the members present at the meeting.

20 (4) A director shall disqualify himself from voting on

21 any issue in which he has a conflict of interest unless such

22 director has disclosed such conflict of interest in compliance

23 with section 18-8-308, C.R.S., in which case such disclosure

24 shall cure the conflict. A director shall abstain from voting

25 if the director would obtain a personal financial gain from

26 the contract or services being voted upon by the authority.

25-8.5-108. Meetings. (1) The board shall fix the time 
1 and place at which its regular meetings shall be held and 2 provide for the calling and holding of special meetings.

(2) Notice of the time and place designated for all regular meetings shall be posted at the office of the county clerk and recorder of each of the counties included within the authority. Such notices shall remain posted and shall be changed in the event that the time or place of such regular meetings is changed.

(3) Special meetings of the board shall be held at the call of the chairman or upon request of two board members. The authority shall inform all board members five calendar days before the special meeting and shall post notice in accordance with subsection (2) of this section at least three days before the special meeting of the date, time, and place of such special meeting and the purpose for which it is called.

(4) All business of the board shall be conducted only during said regular or special meetings, and all said meetings shall be open to the public, but the board may hold executive sessions as provided in article 9 of title 29, C.R.S.

25-8.5-109. Powers of board - organization administration. (1) The board has the following powers relating to carrying on the affairs of the authority:

(a) To organize, adopt bylaws and rules of procedure, and select a chairman and chairman pro tempore;

(b) To make and pass resolutions and orders which are necessary for the governance and management of the affairs of 
1 the authority, for the execution of the powers vested in the

2 authority, and for carrying out the provisions of this

3 article;

4 (c) To fix the location of the principal place of 5 business of the authority and the location of all offices 6 maintained under this article;

11 bonds necessary for the protection of the funds and property 12 of the authority;

13 (e) To appoint and retain employees, agents, and 14 consultants to make recommendations, coordinate authority 15 activities, conduct routine business of the authority, and act 16 on behalf of the authority under such conditions and 17 restrictions as shall be fixed by the board;

18 (f) To prescribe a method of auditing and allowing or 19 rejecting claims and demands and a method for the letting of 20 contracts on a fair and competitive basis for the construction 21 of works, structures, or equipment or for the performance or 22 furnishing of such labor, materials, or supplies as may be 23 required for the carrying out of any of the purposes of this 24 article.

25 25-8.5-110. Powers of authority - general and financial. 26 (1) In order to accomplish its purposes, the authority has 27 the power to: 
1 (a) Develop and implement, with such revisions as become 2 necessary in light of changing conditions, plans for water 3 quality controls for the applicable drainage basin, waters, 4 and watershed;

5 (b) Conduct pilot studies and other studies that may be 6 appropriate for the development of potential water quality 7 control solutions;

9 and rewards for water quality control projects;

11 to maintain the water quality standards and allocate, as 12 allowed by federal and state law, wasteloads among both 13 present and future sources of pollutants;

14 (e) Recommend erosion controls and urban runoff control 15 standards;

21 proceedings;

22

(k) Enter into contracts and agreements affecting the 23 affairs of the authority including, but not limited to, 24 contracts with the United States and the state of Colorado and 25 any of their agencies or instrumentalities, political 26 subdivisions of the state of colorado, corporations, and 27 individuals; 
1 (1) Acquire, hold, lease (as lessor or lessee), and 2 otherwise dispose of and encumber real and personal property; 3 (m) Have and exercise the power of eminent domain with 4 respect to rights-of-way and sites for drainage and nonpoint 5 source or runoff water quality control facilities as provided 6 in article 1 of title 38, C.R.S.;

7 (n) Acquire, lease, rent, manage, operate, construct, 8 and maintain water quality control facilities or improvements 9 for drainage, nonpoint sources, or runoff within or without 10 the authority;

11 (0) Establish rates, tolls, fees, charges, and penalties 12 for the functions, services, facilities, and programs of the 13 authority;

14 (p) Levy and collect ad valorem taxes on and against all 15 taxable property within the authority subject to the 16 limitation that no levy for any fiscal year shall exceed two 17 mills;

18 (q) Issue and refund revenue and assessment bonds and 19 pledge the revenues of the authority or assessments therefor 20 to the payment thereof in the manner provided in part 4 of 21 article 35 of title 31 , C.R.S., and as provided in this 22 article;

$23(r)$ Invest any moneys of the authority in any manner 24 permitted by law;

25 (s) Review and approve water quality control projects of 26 any entity other than the authority within the boundaries of 27 the authority; 
1 (t) Have and exercise all rights and powers necessary or 2 incidental to or implied from the specific powers granted to 3 the authority by this article. Such specific powers shall not 4 be considered as a limitation upon any power necessary or 6 article.

9 revenue or assessment bonds of the authority. Bonds shall 10 bear interest at a rate such that the net effective interest 11 rate of the issue of bonds does not exceed the maximum 12 interest rate set forth in the resolution adopted by the board 13 authorizing the issuance of the bonds, payable semiannually, 14 and shall be due and payable serially, either annually or

16 of issuance. The form and terms of said bonds, including 17 provisions for their payment and redemption, shall be 18 determined by the board. If the board so determines, such 19 bonds may be redeemable prior to maturity upon payment of a 20 premium not exceeding three percent of the principal thereof. 21 Said bonds shall be executed in the name and on behalf of the 22 authority, signed by the chairman of the board with the seal 23 of the authority affixed thereto, and attested by the 24 secretary of the board. Said bonds shall be in such 25 denominations as the board shall determine, and the bonds and 26 coupons shall bear the original or facsimile signature of the 27 chairman of the board. 
25-8.5-112. Revenue refunding bonds. Any revenue bonds

2 issued by the authority may be refunded by the authority, or

3 by any successor thereof, in the name of the authority,

4 subject to the provisions concerning their payment and to any

5 other contractual limitations in the proceedings authorizing

6 their issuance or otherwise appertaining thereto, by the

7 issuance of bonds to refund, pay, and discharge all or any

8 part of such outstanding bonds, including any interest on the

9 bonds in arrears or about to become due, for the purpose of 10 avoiding or terminating any default in the payment of the 11 interest on and principal of the bonds, of reducing interest 12 costs or effecting other economies, or of modifying or 13 eliminating restrictive contractual limitations appertaining 14 to the issuance of additional bonds or to any system 15 appertaining thereto or for any combination of such purposes. 16 Refunding bonds may be delivered in exchange for the 17 outstanding bonds refunded or may be sold as provided in this 18 article for an original issue of bonds.

19 25-8.5-113. Use of proceeds of revenue refunding bonds. 20 The proceeds of revenue refunding bonds shall either be 21 immediately applied to the retirement of the bonds being 22 refunded or be placed in escrow in any state or national bank 23 within the state which is a member of the federal deposit 24 insurance corporation to be applied to the payment of the 25 bonds being refunded upon their presentation therefor; but, to 26 the extent any incidental expenses have been capitalized, such 27 refunding bond proceeds may be used to defray such expenses, 
1 and any accrued interest and any premium appertaining to a

2 sale of refunding bonds may be applied to the payment of the

3 interest thereon or the principal thereof, or both interest

4 and principal, or may be deposited in a reserve therefor, as

5 the board may determine. Any such escrow shall not

6 necessarily be limited to proceeds of refunding bonds but may

7 include other moneys available for its purpose. Any proceeds

8 in escrow, pending such use, may be invested or reinvested in

9 any items permitted by the state of Colorado and bills,

10 certificates of indebtedness, notes, or bonds which are direct

11 obligations of, or the principal and interest of which

12 obligations are unconditionally guaranteed by, the United

13 States. Such proceeds and investments in escrow, together

14 with any interest to be derived from any such investment,

15 shall be in an amount at all times sufficient as to principal,

16 interest, any prior redemption premium due, and any charges of

17 the escrow agent payable therefrom to pay the bonds being

18 refunded as they become due at their respective maturities or

19 due at any designated prior redemption dates in connection

20 with which the board shall exercise a prior redemption option.

21 Any purchase of any refunding bond issued under this article

22 shall in no manner be responsible for the application of the

23 proceeds thereof by the authority or any of its officers,

24 agents, or employees.

25 25-8.5-114. Facilities - comprehensive program.

26 (1) The authority, acting by and through the board, may

27 acquire, construct, lease, rent, improve, equip, relocate, 
1 maintain, and operate water quality control facilities, any

2 project, or any part thereof for the benefit of the authority

3 and the inhabitants thereof, after the board has made such

4 preliminary studies and otherwise taken such action as it

5 determines to be necessary or desirable.

6 (2) (a) The authority shall develop a comprehensive

7 program for the water quality control facilities specified in

8 subsection (1) of this section. A comprehensive program may

9 consist of one project or more than one project.

10 (b) A hearing on the proposed comprehensive program

11 shall be scheduled, and notice of the hearing shall be given

12 by publication and posted in the office of the county clerk

13 and recorder of each member county. Upon closure of the

14 hearing, the board may either require changes to be made in

15 the comprehensive program or the board may approve or reject

16 the comprehensive program as prepared.

17 (c) If any substantial changes to the comprehensive

18 program are ordered at any time, a further hearing shall be

19 held pursuant to notice which shall be given by publication.

20 25-8.5-115. Power to levy special assessments. (1) The

21 board, in the name of the authority, for the purpose of

22 defraying all the cost of acquiring or constructing, or both,

23 any project or facility authorized by this article, or any

24 portion of the cost thereof not to be defrayed with moneys

25 available therefor from its own funds, any special funds, or

26 otherwise, also has the power under this article:

27 (a) To levy assessments against all or portions of the 
1 property within the authority and to provide for collection of

2 the assessments pursuant to part 6 of article 20 of title 30 , 3 C.R.S.;

(b) To pledge the proceeds of any assessments levied under this article to the payment of assessment bonds and to create liens on such proceeds to secure such payments;

(c) To issue assessment bonds payable from the 8 assessments, which assessment bonds shall constitute special 9 obligations of the authority and shall not be a debt of the 10 authority; and

11 (d) To make all contracts, to execute all instruments, 12 and to do all things necessary or convenient in the exercise 13 of the powers granted in this article or in the performance of 14 the authority's duties or in order to secure the payment of 15 its assessment bonds.

16 (2) The authority shall give notice, by publication once 17 in a newspaper of general circulation in the authority, to the 18 owners of the property to be assessed, which shall include:

21 cost of the project will be payable;

(c) A description of the properties which will be 23 assessed;

24 (d) The probable cost per acre or other unit basis 25 which, in the judgment of the authority, reflects the benefits which accrue to the properties to be assessed;

(e) The time, not less than thirty days after the 
1 publication, when a resolution authorizing the improvements

2 will be considered;

3 (f) A map of the properties to be assessed, together

4 with an estimate and schedule showing the approximate amounts

5 to be assessed, and a statement that all resolutions and 6 proceedings are on file and may be seen and examined by any

7 interested person at the office of the authority or other

8 designated place at any time within said period of thirty

9 days; and

10 (g) A statement that all complaints and objections by 11 the owners of property to be assessed in writing concerning

12 the proposed improvements will be heard and determined by the 13 authority before final action thereon.

14 (3) The finding, by resolution, of the board that said 15 improvements were ordered after notice given and after hearing 16 held and that such proposal was properly initiated by the said 17 authority shall be conclusive of the facts so stated in every 18 court or other tribunal.

19 (4) Any resolution or order regarding the assessments or 20 improvements may be modified, confirmed, or rescinded at any 21 time prior to the passage of the resolution authorizing the 22 improvements. territory.

24 municipality, county, or special district, or any portion 25 thereof, shall be eligible for inclusion upon resolution of 26 its governing body requesting inclusion in the authority and 27 describing the property to be included. The authority, by 
1 resolution, may include such property on such terms and 2 conditions as may be determined appropriate by the board.

3 (2) Upon receipt of a resolution requesting inclusion, 4 the board shall cause an investigation to be made within a 5 reasonable time to determine whether or not the municipality, 6 county, or special district, or portion thereof, may feasibly 7 be included within the authority, whether the municipality, 8 county, or special district has any property which is 9 tributary to the basin, waters, or watersheds governed by the authority, and the terms and conditions upon which the 11 municipality, county, or special district may be included 12 within the authority. If it is determined that it is feasible 13 to include the municipality, county, or special district, or 14 portion thereof, in the authority, and the municipality, 15 county, or special district has property tributary to the 16 basin, waters, or watersheds governed by the authority, the 17 board by resolution shall set the terms and conditions upon 18 which the municipality, county, or special district, or 19 portion thereof, may be included within the authority and 20 shall give notice thereof to the municipality, county, or 21 special district. If the board determines that the 22 municipality, county, or special district, or portion thereof, 23 cannot feasibly be included within the authority or otherwise 24 determines that the municipality, county, or special district 25 should not be included within the authority, the board shall 26 pass a resolution so stating and notifying the municipality, 27 county, or special district of the action of the board. The 
1 board's determination that the county, municipality, or 2 special district, or portion thereof, should not be included 3 in the authority shall be conclusive.

4

(3) (a) If the governing body of the municipality, county or special district desires to include the municipality, county, or special district, or portion thereof, within the authority upon the terms and conditions set forth by the board, the governing body shall adopt a resolution declaring that the public health, safety, and general welfare requires the inclusion of said municipality, county, or special district within the authority and that the governing body desires to have said municipality, county, or special district, or portion thereof, included therein upon the terms and conditions prescribed by the board. The governing body of such municipality, county, or special district, before final adoption of said resolution, shall hold a public hearing thereon, notice of which shall be given by publication in a newspaper of general circulation within such municipality, county, or special district, which shall be complete at least ten days before the hearing. Upon the final adoption of said resolution, the clerk of the governing body of such municipality, county, or special district shall forthwith transmit a certified copy of the resolution to the board and to the division of local government in the department of local affairs.

(b) After receipt of a copy of such resolution, the board shall pass and adopt a resolution including said 
1 municipality, county, or special district, or portion thereof, 2 in the authority and shall cause a certified copy thereof to

3 be transmitted to the division of local government and a 4 certified copy to the governing body of the municipality, 5 county, or special district.

(4) The director of said division, upon receipt of a certified copy of the resolution of the board, shall forthwith issue a certificate reciting that the municipality, county, or special district, or portion thereof, described in such 11 according to the laws of the state of Colorado. The inclusion 12 of such territory shall be deemed effective upon the date of 13 the issuance of such certificate, and the validity of such 14 inclusion shall not be contestable in any suit or proceeding 15 which has not been commenced within thirty days from such 16 date. The said division shall forthwith transmit to the 17 governing body of such municipality, county, or special 18 district and to the board five copies of such certificate, and 19 the clerk of such governing body shall forthwith record a copy 20 of the certificate in the office of the clerk and recorder of 21 each county in which such municipality, county, or special 22 district, or portion thereof, is located and file a copy 23 thereof with the county assessor of each such county. 24 Additional copies of said certificate shall be issued by the 25 division of local government upon request. 25-8.5-117. Exclusion of property. (1) Any owner of 27 property within the boundaries of the authority may petition 
1 to be excluded from the authority.

2 (2) In order for such property to be excluded, the board 3 shall determine that the property to be excluded does not 4 receive wastewater treatment services or have an individual 5 sewage disposal system located within the authority and 6 either:

9 governed by the authority or will not benefit from projects or 10 improvements provided by the authority.

11 (3) Any petition for exclusion shall specify the 12 property to be excluded, and evidence that the property 13 complies with the criteria of subsection (2) of this section. 14 (4) The authority shall provide notice of the date, 15 time, and place of the authority's meeting to consider the 16 petition for exclusion.

17 (5) The authority may approve, modify, or deny a 18 petition for exclusion.

19 (6) If the authority approves a petition for exclusion 20 of property, the authority shall file a copy of said 21 resolution with the division of local government and with the 22 county, municipality, or special district authority members 23 which includes within its boundaries the excluded property, 24 record a copy of the resolution in the office of the county 25 clerk and recorder in the county in which said excluded 26 property is located, and file a copy with the county assessor 27 in such county. 
1 SECTION 2. Safety clause. The general assembly hereby 2 finds, determines, and declares that this act is necessary 3 for the immediate preservation of the public peace, health, 4 and safety. 
BILL 6

A BILL FOR AN ACT

1 CONCERNING AMENDMENTS TO THE "COLORADO CHEMIGATION ACT", AND 2 RELATING TO THE DEFINITIONS OF "CHEMIgATION" AND 3 "IRRIGATION", AN INCREASE IN THE PERMIT AND INSPECTION FEES, AND THE PENALTIES PROVIDED FOR VIOLATIONS OF THE $5 \quad$ ACT.

\section{Bill Summary}

(Note: This summary applies to this bill as introduced and does not necessarily reflect any amendments which may be subsequently adopted.)

Deletes from the definition of "chemigation" language which limited the application of the "Colorado Chemigation Act" to wells which are greater than two inches in diameter and have been issued a well permit by the state engineer. Enlarges the definition of "irrigation" to include any device or combination of devices having a hose, pipe, or other conduit which connects directly to any source of ground water or surface water. Increases the fees for permits and imposes a limit on the fee for an inspection. Changes the penalty for violating the provisions of the act from a class 5 felony to a misdemeanor.

6 Be it enacted by the General Assembly of the State of Colorado:

$$
\text { SECTION 1. 35-11-102 }
$$

(2) and

(8), Colorado Revised

8 Statutes, 1984 Repl. Vol., as amended, are amended to read: 
35-11-102. Definitions. (2) "Chemigation" means any

2 process whereby chemicals are applied to land or crops in or

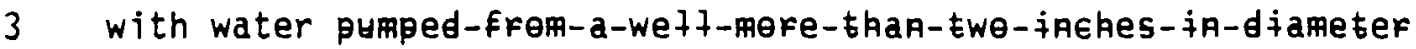

4 Whith-has-been-issued-a-permit-by-the-state-engineef THROUGH A

5 CLOSED IRRIGATION SYSTEM. "Chemigation" does not mean any

6 process whereby chemicals are applied to land or crops in or

7 with water pumped from a stock watering well or a domestic

8 well with a diameter of two inches or less.

9 (8) "Irrigation system" means any device or combination

10 of devices having a hose, pipe, or other conduit, which

11 connects directly to any source of ground water by-means-ef-a

12 watef-wełl-whith--has--been--issued--a--peftit--by--the--state

13 engineef OR SURFACE WATER, through which water or a mixture of

14 water and chemicals is drawn and applied for eөmmeretat

15 agricultural or eөmefeial horticultural purposes. For

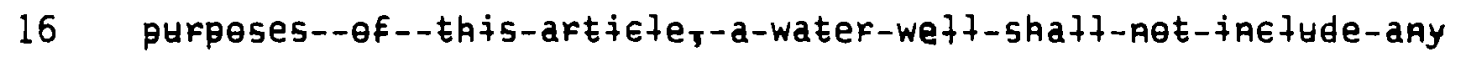

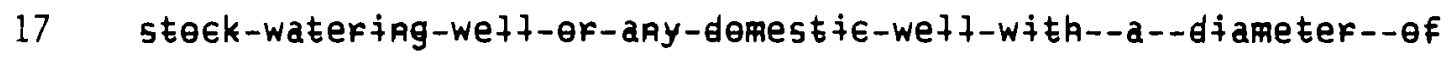

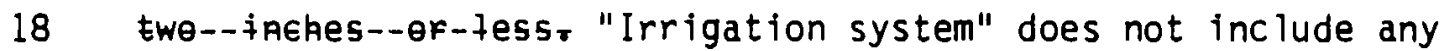

19 hand-held hose sprayer or other similar device which is

20 constructed so that an interruption in water flow

21 automatically prevents any backflow to the water source AND

22 DOES NOT INCLUDE STOCK WATER WELLS OR ANY DOMESTIC WELL WITH A

23 DIAMETER OF TWO INCHES OR LESS.

24 SECTION 2. 35-11-105 (4), Colorado Revised Statutes,

251984 Repl. Vol., as amended, is amended to read:

26 35-11-105. Issuance of provisional chemigation permit -

27 fees. (4) The fee for a provisional chemigation permit and 
1 the annual renewal permit shall be established by rule and 2 regulation of the commissioner and shall reflect all direct 3 and indirect costs for the administration of this article but 4 shall not exceed sixty-five ONE HUNDRED dollars. The 5 inspection fee for a provisional chemigation permit shall be 6 established by the commissioner and shall reflect all direct 7 and indirect costs of the inspection BUT SHALL NOT EXCEED 8 EIGHTY DOLLARS. A provisional chemigation permit shall expire 9 on March 31 of the year subsequent to the date the provisional 10 chemigation permit was issued. The reinstatement fee for an 11 expired provisional chemigation permit shall be double the 12 amount of the fee for a provisional chemigation permit. A 13 provisional chemigation permit shall not be assignable. SECTION 3. 35-11-106 (3), Colorado Revised Statutes, 1984 Rep 1. Vol., as amended, is amended to read:

17 (3) The fee for a chemigation permit and the annual renewal 18 fee shall be established by the commissioner through rules and 19 regulations. Such fees shall reflect all direct and indirect 20 costs of the department for the administration of this article 21 but shall not exceed forty ONE HUNDRED dollars. The 22 inspection fee shall be established by rule and regulation of 23 the commissioner and shall reflect all direct and indirect 24 costs for the inspection BUT SHALL NOT EXCEED EIGHTY DOLLARS. 25 A chemigation permit shall expire on March 31 of the year 26 subsequent to the date the chemigation permit was issued. The 27 reinstatement fee for an expired chemigation permit shall be 
1 double the amount of the fee for a chemigation permit. The 2 reinstatement fee shall not be assessed to any person who 3 flled an affidavit in lieu of a permit for the year prior to 4 the year such person seeks a permit. A chemigation permit 5 shall not be assignable.

12 CONVICTION THEREOF, SHALL BE PUNISHED BY A FINE OF NOT MORE 13 THAN TWO THOUSAND DOLLARS, OR BY IMPRISONMENT IN THE COUNTY 14 JAIL FOR NOT MORE THAN ONE HUNDRED EIGHTY DAYS, OR BY BOTH 15 SUCH FINE AND IMPRISONMENT. EACH DAY IN WHICH A VIOLATION 16 OCCURS SHALL CONSTITUTE A SEPARATE OFFENSE.

17 SECTION 5. Effective date. This act shall take effect 18 July $1,1988$.

19 SECTION 6. Safety clause. The general assembly hereby 20 finds, determines, and declares that this act is necessary 21 for the immediate preservation of the public peace, health, 22 and safety. 
BILL 7

A BILL FOR AN ACT

1 CONCERNING AN APPROPRIATION TO THE DEPARTMENT OF NATURAL RESOURCES FOR ALLOCATION TO THE STATE ENGINEER.

\section{Bill Summary}

(Note: This summary applies to this bill as introduced and does not necessarily reflect any amendments which may be subsequentiy adopted.)

Makes an appropriation to the department of natural resources for allocation to the state engineer for purposes of administering the state's water compacts.

3 Be it enacted by the General Assembly of the State of Colorado:

SECTION 1. Appropriation. In addition to any other

5 appropriation, there is hereby appropriated, out of any moneys

6 in the general fund not otherwise appropriated, to the

7 department of natural resources for allocation to the state

8 engineer, for the fiscal year beginning July 1, 1988, the sum

9 of dollars (\$_ ) and FTE, or so much

10 thereof as may be necessary, for administering the state's

11 water compacts.

12 SECTION 2. Safety clause. The general assembly hereby 
1 finds, determines, and declares that this act is necessary

2 for the immediate preservation of the public peace, health, 3 and safety. 
BILL 8

A BILL FOR AN ACT

1 CONCERNING PROJECTS FUNDED BY THE COLORADO WATER CONSERVATION 2 BOARD CONSTRUCTION FUND, AND RELATING TO THE ACTIVITIES 3 OF THE COLORADO WATER CONSERVATION BOARD IN CONNECTION 4 THEREWITH.

\section{Bill Summary}

(Note: This summary applies to this bill as introduced and does not necessarily reflect any amendments which may be subsequently adopted.)

Approves water resources projects for financial assistance loans out of the Colorado water conservation board construction fund.

5 Be it enacted by the General Assembiy of the State of Colorado:

6 SECTION 1. Project authorization. (1) Pursuant to

7 section 37-60-122 (1) (b), Colorado Revised Statutes, the

8 Colorado water conservation board is hereby authorized to loan

9 moneys to enable the construction of the following water

10 resources projects: 


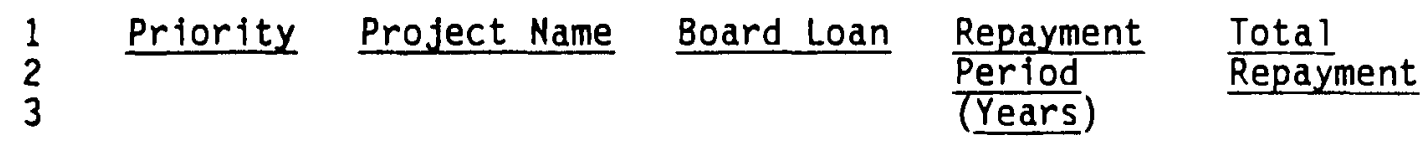

4 (2) The Colorado water conservation board may make loans

5 for the construction of each project specified in subsection

6 (1) of this section from such moneys as are or may hereafter 7 become avaflable to the Colorado water conservation board 8 construction fund, said loans to be in the amounts listed in 9 said subsection (1) plus or minus such amounts, if any, as may 10 be justified by reason of ordinary fluctuations in 11 construction costs as indicated by the engineering cost 12 indices applicable to the types of construction involved for 13 such projects or as may be justified by reason of changes made 14 in the plans for a project if those changes are required by 15 final engineering drawings and specifications or by federal or 16 state requirements. The board's loan for any project 17 specified in subsection (1) of this section shall not exceed 18 fifty percent of the total cost of constructing a project.

19 (3) Contracts entered into by the Colorado water 20 conservation board pursuant to section 37-60-119 (2), Colorado 21 Revised Statutes, for loans to enable the construction of the 22 profects specified in subsection (1) of this section shall be 23 subject to the repayment periods and total repayments set 
1 forth therein; except that total repayments shall be adjusted

2 to reflect any changes in the amounts loaned by reason of 3 subsection (2) of this section.

4 SECTION 2. Safety clause. The general assembly hereby

5 finds, determines, and declares that this act is necessary

6 for the immediate preservation of the public peace, health, 7 and safety. 
JOINT RESOLUTION A

\begin{abstract}
WHEREAS, The "Federal Water Pollution Control Act Amendments of 1972", as amended by the federal "Clean Water Act of 1977", were enacted to "restore and maintain the chemical, physical, and biological integrity of the nation's waters", and section 404 of the "Clean Water Act" authorizes the Secretary of the Army, acting through the Chief of the U.S. Army Corps of Engineers, to issue permits for the discharge of dredged or fill material into the waters of the United States applying guidelines developed by the Administrator of the Environmental Protection Agency in conjunction with the Secretary of the Army; and
\end{abstract}

WHEREAS, Section 404 has expanded the regulatory authority of the Corps from traditional navigable waters to "waters of the United States" which has been construed by some to encompass practically all waters and wetlands; and

WHEREAS, The "Clean Water Act" calls for minimization of duplication, needless paperwork, and delays in issuance of permits and sets a target of ninety days for a final decision on an application for a section 404 permit. For this purpose, the Secretary of the Army is required to develop agreements with heads of other agencies, such as the EPA and the Departments of Interior and Commerce, which have statutory responsibilities for advising the Corps about environmental, wlldlife, and other impacts of permit applications; and

WHEREAS, In administering its regulatory program, the Corps is subject to a large number of statutory, executive, and regulatory constraints requiring extensive documentation; and

WHEREAS, The State of Colorado is divided and managed by five different U.S. Army Corps of Engineers Districts, whose offices are all located in other states; and

WHEREAS, Multiple districts of tentimes cause confusion as 
1 situations where transbasin projects are subject to different 2 interpretations of rules and regulations by different 3 districts; and

WHEREAS, The enforcement of the provisions of the 404 permit program is difficult to monitor due to the extreme distances between the district offices and projects in Colorado and only two of the five districts maintain local offices in Colorado; and

WHEREAS, Permit applicants from the public and private 10 sectors point to inconsistencies among the different Corps 11 districts in administering the program; and

WHEREAS, There is a need for a local presence in the state by the Corps and a need for consistent application of rules and regulations to 404 permits originating within the state; now, therefore,

Be It Resolved by the House of Representatives of the Fifty-sixth General Assembly of the State of Colorado, the Senate concurring herein:

The United States Army Corps of Engineers consolidate their district boundaries for the state of Colorado into one district and continue to maintain a local presence in the state.

Be It Further Resolved, That copies of this Resolution be transmitted to the United States Army Corps of Engineers, the Colorado Congressional delegation, the United States Department of Interior, the United States Department of Commerce, the United States Fish and Wildlife Service, the Soil Conservation Service, the Environmental Protection Agency, the Colorado Joint Review Process, and the Colorado Division of Wildlife. 